JULIANA ANDREONI NICO

\title{
Evidências de redundância funcional entre as pró-hormônio convertases no processamento pós-traducional do precursor da vitelogenina VIT-6 do nematóide Caenorhabditis elegans
}

Tese apresentada ao Instituto de Ciências Biomédicas da Universidade de São Paulo, para obtenção do Título de Doutor em Ciências.

Área de concentração: Biologia da Relação Patógeno-Hospedeiro

Orientador: Prof. Dr. Carlos Eduardo Winter 


\section{RESUMO}

ANDREONI-NICO, J. Evidências de redundância funcional entre as pró-hormônio convertases no processamento pós-traducional do precursor da vitelogenina VIT-6 do nematóide Caenorhabditis elegans. 2008. Tese (Doutorado em Parasitologia) Instituto de Ciências Biomédicas, Universidade de São Paulo, São Paulo, 2008.

Diversas proteínas são sintetizadas na forma de polipeptídeos inativos e suas atividades dependem da clivagem pós-traducional após um par de aminoácidos básicos. Em vários sistemas, de mamíferos a insetos, foi descrita uma família de serina peptidases que reconhecem o sítio consenso de clivagem $\mathrm{R}-\mathrm{X}-\mathrm{K} / \mathrm{R}-\mathrm{R}$. Essas enzimas foram denominadas pró-hormônio convertases ou apenas PCs e são similares à subtilisina bacteriana e à kexina de leveduras. No genoma do nematóide de vida livre, Caenorhabditis elegans, quatro genes de kpcs (kex2/subtilisin-like proprotein convertases) são encontrados ( $k p c-1, k p c-2 / e g l-3, k p c-3 / a e x-5$ e $k p c-4 / b l i-4)$, sendo $k p c$ 1 o mais similar à furina humana e à convertase de vitelogenina de Aedes aegypti (AeVC). Em C. elegans, dois dos quarto polipeptídeos de vitelogenina encontrados dentro dos ovócitos, YP115 e YP88, se originam de um precursor polipeptídico clivado pós-traducionalmente, codificado pelo gene vit-6. O provável sítio de clivagem da do precursor VIT-6 apresenta resíduos básicos nas posições P4, P2 e P1 (R-G-K-R). O principal objetivo desse trabalho foi verificar o envolvimento de cada uma dessas convertases de $C$. elegans no processamento pós-traducional do precursor de vitelogenina VIT-6. A fim de responder essa questão, dois peptídeos recombinantes correspondentes às regiões $\mathrm{N}$ - e C-terminal de VIT-6 foram expressos em E. coli, purificados e utilizados para produção de anticorpos em camundongos. Os soros monoespecíficos foram utilizados em ensaios de Western-blot para comparar o padrão de processamento de VIT-6 em nematóides selvagens, mutantes e knock-down por interferência de RNA (RNAi) para os diferentes genes de convertases. Nematóides transgênicos foram produzidos através de técnica de transformação por microinjeção utilizando construções contendo repórteres transcricionais do gene da proteína verde flurescente (GFP). As três linhagens produzidas possibilitaram visualizar a expressão de GFP, dirigida por diferentes regiões promotoras do gene $k p c-1$, tanto em neurônios quanto em células musculares e intestinais. Esses dados, aliados aos dados da literatura para os outros genes $k p c$ de C. elegans ( $k p c-2 / e g l-3, k p c-3 / a e x-5, k p c-4 / b l i-4)$, sugerem o envolvimento de KPC-1 tanto no processamento de peptídeos neuronais quanto do precursor de vitelogenina VIT-6, que é sintetizado pelas células intestinais e posteriormente secretado no pseudoceloma. A análise de nematóides mutantes e knockdown por RNAi combinado para genes de convertase de C. elegans (kpc-1, kpc-2/egl-3, $k p c-3 / a e x-5, k p c-4 / b l i-4)$ confirmou a redundância da atividade dessas enzimas em $C$. elegans, apesar de nenhum dos mutantes ou duplos-knock-down apresentarem ausência absoluta de processamento de VIT-6. A convertase KPC-1 recombinante foi produzida em diferentes sistemas de expressão heterólogos com diferentes construções para análise da atividade enzimática, mas nenhuma das construções produziu enzima com atividade que possibilitasse tais estudos.

Palavras-chave: Caenorhabditis elegans. Pró-hormônio convertases. Serino peptidases. Processamento pós-traducional. Nematóides transgênicos. RNAi. Redundância funcional. 


\begin{abstract}
ANDREONI-NICO, J. Evidences of functional redundancy among the proprotein convertases in the post-translational processing of the VIT-6 vitellogenin precursor of the nematode Caenorhabditis elegans. 2008. Ph. D. Thesis (Parasitology) - Instituto de Ciências Biomédicas, Universidade de São Paulo, São Paulo, 2008.

Many biologically important proteins and peptides are synthesized as large inactive precursors and depend on a post-translational cleavage C-terminal to a pair of basic aminoacid residues for its activation. In many systems, from mammals to insects, a family of serine peptidases that recognize the consensus cleavage site $R-X-K / R-R$ has been described as being similar to the bacterial subtilisin and the yeast kexin and have been named proprotein convertases or PCs. In the genome of the free-living nematode, Caenorhabditis elegans, there are four $k p c$ genes (kex2/subtilisin-like proprotein convertases): $k p c-1, k p c-2 / e g l-3, k p c-3 / a e x-5, k p c-4 / b l i-4$. KPC-1, the nematode convertase closely related to the human furin, has also a strong sequence similarity to that of the Aedes aegypti vitellogenin convertase (AeVC). In C. elegans, two of the four vitellogenin polypeptides found inside the oocyte, YP115 and YP88, originate from a proteolytically processed precursor coded by the vit-6 gene. VIT-6 precursor probable site of cleavage shows basic residues in P4, P2 and P1 positions (R-G-K-R). The main objective of this study was to verify each of these convertases involvement in the processing of VIT-6 vitellogenin in C. elegans. In order to address this question, two recombinant polypeptides with approximately $20 \mathrm{kDa}$ each, corresponding to $\mathrm{N}$ - and $\mathrm{C}$ terminal regions of VIT-6, were expressed in E. coli. Monospecific antisera against these recombinant polypeptides were raised in mice and were used to analyze VIT-6 processing in wild-type, knock-out ( $k p c$ mutants) and knock-down (RNA interference treated) worms, the two latter lacking most of KPC activity. Western-blot analyses of the VIT-6 processing showed a possible redundant role within the KPC family members since any of the mutants/knock-down animals showed complete lack of processing. Transgenic worms were produced carrying transcriptional reporter constructs of the green fluorescent protein (GFP) driven by different promoter regions of $k p c-1$ gene. GFP expression could be detected both in neuronal cells, showing possible involvement of KPC-1 in the cleavage of neuronal peptides and hormones, and muscular and intestinal cells, which suggests its probable role in vitellogenin VIT-6 processing, since this precursor is also synthesized in the gut and secreted to the pseudocoelom. Analysis of mutant and combined knocked-down nematodes for the four $k p c$ genes $(k p c-1, k p c$ 2/egl-3, kpc-3/aex-5, kpc-4/bli-4) confirmed the redundant activity of these enzymes, since none of these mutants alone show absence of VIT-6 processing. Recombinant KPC-1 was produced in E. coli and insect cells but no activity could be detected from the recombinant KPC-1 purified from any of these systems.
\end{abstract}

Keywords: Caenorhabditis elegans. Pro-hormone convertases. Serine peptidases. Posttranslational processing. Transgenic nematodes. RNAi. Functional redundancy. 


\section{Introdução}




\subsection{Nematóides}

À primeira vista, a superficial simplicidade morfológica e anatômica dos nematóides pode levar um observador despreparado a compreendê-los como um filo que pode ser generalizado e exemplificado através de uma única espécie modelo, Caenorhabditis elegans. Engana-se. Os nematóides são um grupo altamente diversificado em todos os aspectos. São encontrados colonizando desde sedimentos marinhos a desertos e podem ter hábitos alimentares diversos, podendo ser bacterióvoros, parasitas obrigatórios de plantas ou de animais e até mesmo canibais. Essa variação ecológica reflete-se em uma extensa diversidade morfológica fruto de adaptação (DE LEY, 2006).

Em análises mais aprofundadas, quando processos biológicos são analisados, algumas espécies de nematóides podem parecer mais próximas evolutivamente de outros metazoários do que do próprio organismo modelo $C$. elegans, indicando que a evolução neste grupo não tende a seguir um padrão (DE LEY, 2006).

Frente a tamanha diversidade, ao acúmulo cada vez maior de informações a respeito das espécies de nematóides e ao número crescente de espécies que ainda vêm sendo descobertas e identificadas, torna-se necessária a construção de uma filogenia consistente na qual se pode basear comparações entre diferentes grupos e espécies dentro do Filo Nematoda.

A primeira análise filogenética molecular do filo Nematoda baseada em dados moleculares foi realizada por Blaxter, na qual foram analisadas sequências de RNA da subunidade menor do ribossomo de 53 espécies (BLAXTER et al., 1998). Atualmente, já estão disponíveis em bancos de dados virtuais essas sequências para 600 diferentes espécies e mesmo assim, a análise inicial de Blaxter continua apresentando um embasamento forte.

A classificação de De Ley e Blaxter (2002) (Figura 1.1), baseada na sequência de RNA da subunidade menor do ribossomo, divide o Filo Nematoda em três subclasses: Cromadoria, Enoplia e Dorilaimia. Membros das subclasses Enoplia e Dorilaimia diferem consideravelmente em vários aspectos da espécie Caenorhabditis elegans, membro da subclasse Cromadoria. Esta última subclasse inclui a ordem Rhabditida na qual encontramos, entre outros, os gêneros Oscheius e Caenorhabditis.

Os Enoplia são espécies de ambientes marinhos e de água doce e solos úmidos, sendo muitos deles predadores e nenhum parasita de animais. A dispersão dos Cromadoria é interessante pois são encontrados em uma extensa variedade de habitats. 
A evolução da cutícula impermeável dos membros da ordem Rhabditida pode ser considerada um passo chave na adaptação dessas espécies parasitas, colonizadoras e extremófilas (DE LEY, 2006).
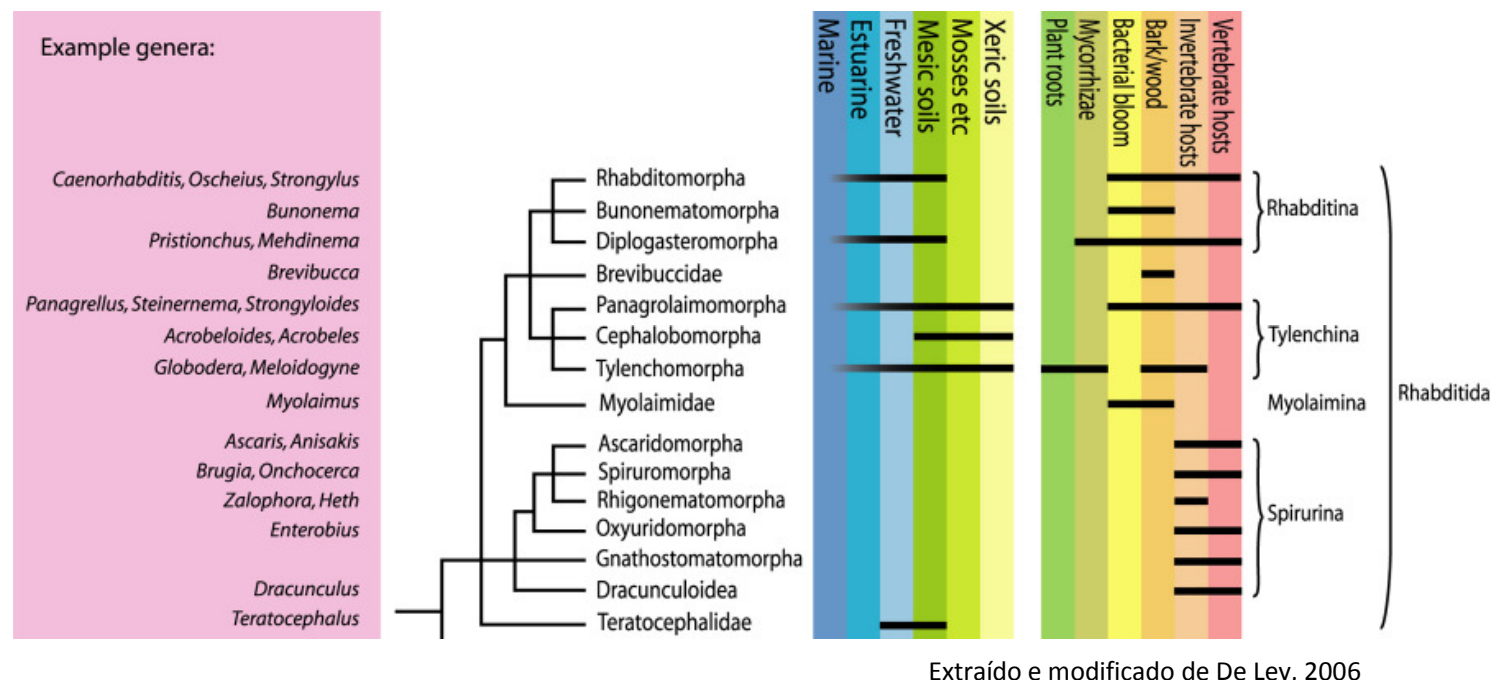

Extraído e modificado de De Ley, 2006

Figura 1.1:Ordem Rhabditida. Análise filogenética baseada em sequências da subunidade menor do RNA ribossômico incluindo exemplos de táxons e nicho ecológico.

A espécie de vida livre C. elegans está incluída entre os Rhabditomorpha juntamente com espécies zooparasitas como Haemonchus contortus e Nippostrongylus brasiliensis (MELDAL et al., 2007). Comparando-se os dados de ESTs disponíveis dessas diferentes espécies com os de C. elegans foi observada uma similaridade entre as seqüências variando de 50 a 70\% (PARKINSON et al., 2004).

A anatomia desses animais está baseada numa estrutura de dois tubos concêntricos separados pelo fluido do pseudoceloma (Figura 1.2). Sua forma é mantida por pressão hidrostática positiva e seu corpo é coberto por uma camada de cutícula de colágeno de composição específica de cada estádio larval, trocada a cada muda. Sob a cutícula, compondo o tubo externo, encontra-se uma camada de hipoderme, conectada às quatro faixas de musculatura longitudinais e que determinam, pela sua contração dorsal ou ventral, a movimentação sinusoidal do verme sobre o substrato (WOOD, 1988). 

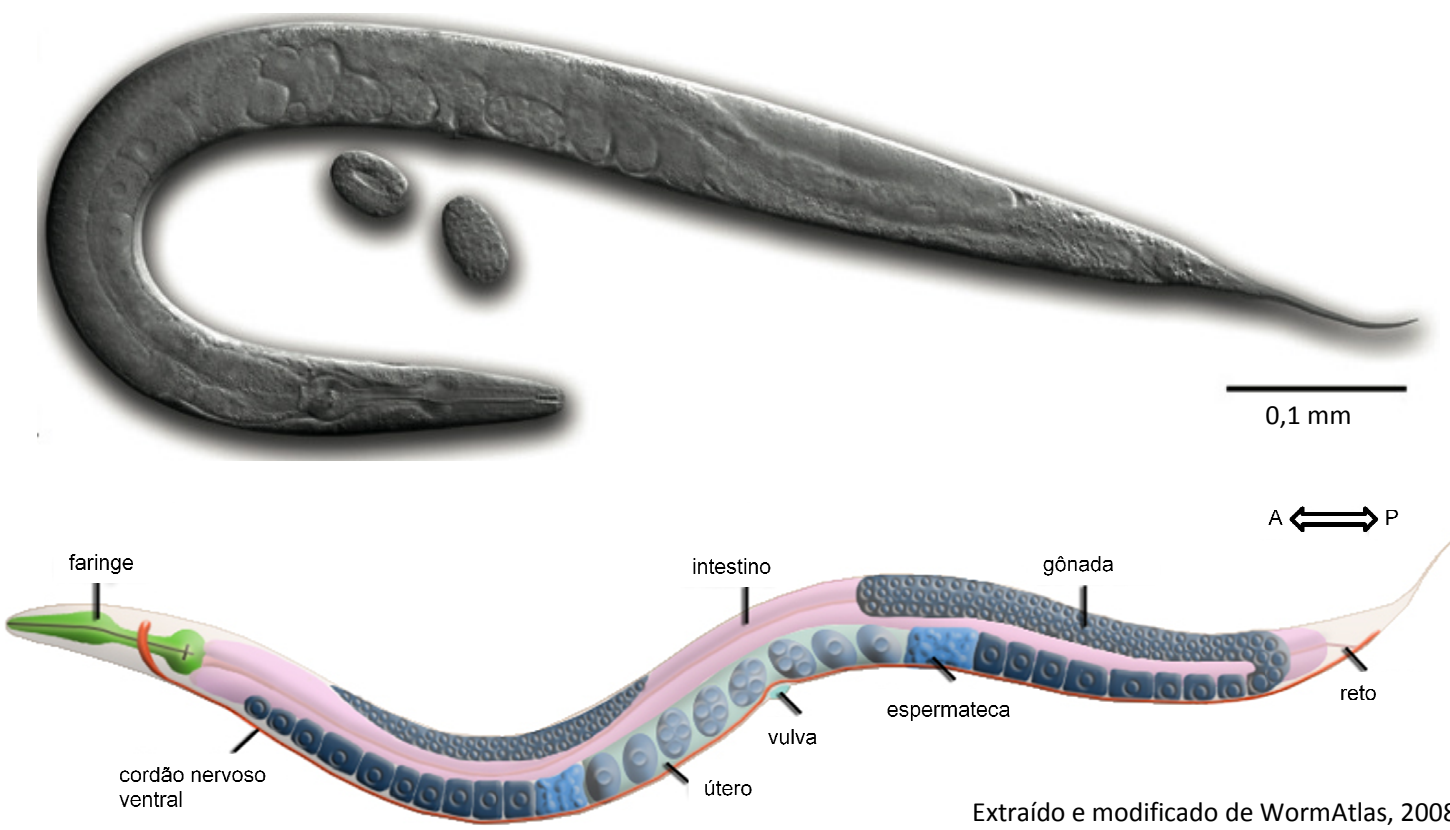

Figura 1.2:Anatomia e morfologia de Caenorhabditis elegans. Acima esquema da morfologia e anatomia de um exemplar adulto hermafrodita de $C$. elegans. Abaixo, DIC de um exemplar adulto hermafrodita com dois ovos postos.

Abaixo da hipoderme estão dispostos os outros componentes desse tubo externo: a gônada, o sistema nervoso, os celomócitos e o sistema excretor. O tubo interno é composto basicamente pelo tubo digestivo. Este é dividido em faringe e intestino. A faringe é um órgão muscular bilobado que bombeia o alimento para o interior do tubo digestivo após triturá-lo no lóbulo posterior. Ao redor da faringe, no anel nervoso, está concentrada a maioria dos corpos celulares dos neurônios que se estendem da cabeça à cauda. Outros estão localizados na cauda e ao longo do cordão nervoso ventral. A gônada é composta por dois braços, anterior e posterior. Os ovários estão dispostos distalmente em relação à vulva que é central. Os ovócitos se desenvolvem ao longo do ovário, até atravessarem a espermateca, onde são fertilizados. A região distal dos ovários é composta de ovócitos acelulares em sincício e sofrem celularização ao longo do desenvolvimento até atingirem o útero. O útero é comum e central, carregando os ovos contendo embriões já em desenvolvimento que atravessam a vulva. Os hermafroditas protândricos, ou seja, cujos espermatozóides se diferenciam e amadurecem antes dos ovócitos, se autofecundam (WOOD, 1988; RIDDLE et al., 1997).

Todos os nematóides sofrem quatro mudas ao longo do desenvolvimento. Ainda não são profundamente compreendidos os sinais ambientais e/ou hormonais que ativam a 
cascata de eventos que induzem a muda (PAGE E JOHNSTONE, 2007), mas existem evidências por genômica funcional que apontam a atividade de fatores de transcrição, peptídeos, receptores nucleares de hormônio (KOSTROUCHOVA et al., 2001), proteases (DAVIS et al., 2004) e proteínas de matriz extracelular (FRAND, RUSSEL e RUVKUN, 2005).

Em C. elegans, o envolvimento de colesterol no processo de muda baseia-se mais em analogias com insetos (cuja muda é regulada pela ecdisona - derivada do colesterol através de receptor nucleares de hormônios) do que em evidências diretas. Mutações no gene do receptor nuclear de hormônio $n h r-23$ do nematóide causa defeitos na muda (KOSTROUCHOVA et al., 2001). Foi descrita uma desidrogenase de esteróides (LET767) em C. elegans que pode estar envolvida da síntese e/ou modificação do colesterol em hormônio esteróide (KUERVERS et al., 2003). Apesar dessas evidências, não há nenhum ortólogo ao receptor de ecdisona (EcR) de insetos no genoma do nematóide (YOCHEM et al., 1999). Essas evidências levam à suposição de que a muda em $C$. elegans deva ser regulada por outro hormônio esteróide que não a ecdisona (ENTCHEV e KURZCHALIA, 2005).

\subsubsection{Caenorhabditis elegans como modelo experimental}

Caenorhabditis elegans (Caeno=recente; rhabditis=bastão; elegans=elegante) é um nematóide de vida livre terrestre encontrado em várias partes do Mundo. Pode viver por até 20 dias sob condições favoráveis, além de apresentar uma forma de resistência (larva "dauer") que permite sua sobrevivência sob condições desfavoráveis (temperaturas extremas e/ou falta de alimento) (WOOD, 1988).

Seu genoma tem aproximadamente $10^{8}$ pares de bases e foi o primeiro animal multicelular a ter o genoma completamente seqüenciado (THE C. ELEGANS SEQUENCING CONSORTIUM, 1998).

Inicialmente, os estudos com Caenorhabditis elegans basearam-se na biologia descritiva do nematóide (NIGON E DOUGHERTY, 1949 e DOUGHERTY et al., 1959), fornecendo base aos estudos subseqüentes de Sidney Brenner, até então um geneticista de bacteriófagos, que pretendia utilizar esse nematóide para identificar e compreender o funcionamento do sistema nervoso de eucariotos, considerado então "a última fronteira” da Biologia (WARD, 1975 e SULSTON et al., 1975). 
A posterior eleição de $C$. elegans como um organismo modelo feita então por Brenner em meados da década de 60 do século passado baseou-se em critérios específicos que atendessem às necessidades de sua pesquisa. Primeiramente, ciclo de vida curto (de ovo a adulto em 3 dias a $22{ }^{\circ} \mathrm{C}$ ), possibilitando um aumento significativo no número de indivíduos num curto período de tempo (350 ovos por indivíduo) (BYERLY et al., 1976) (Figura 1.3).

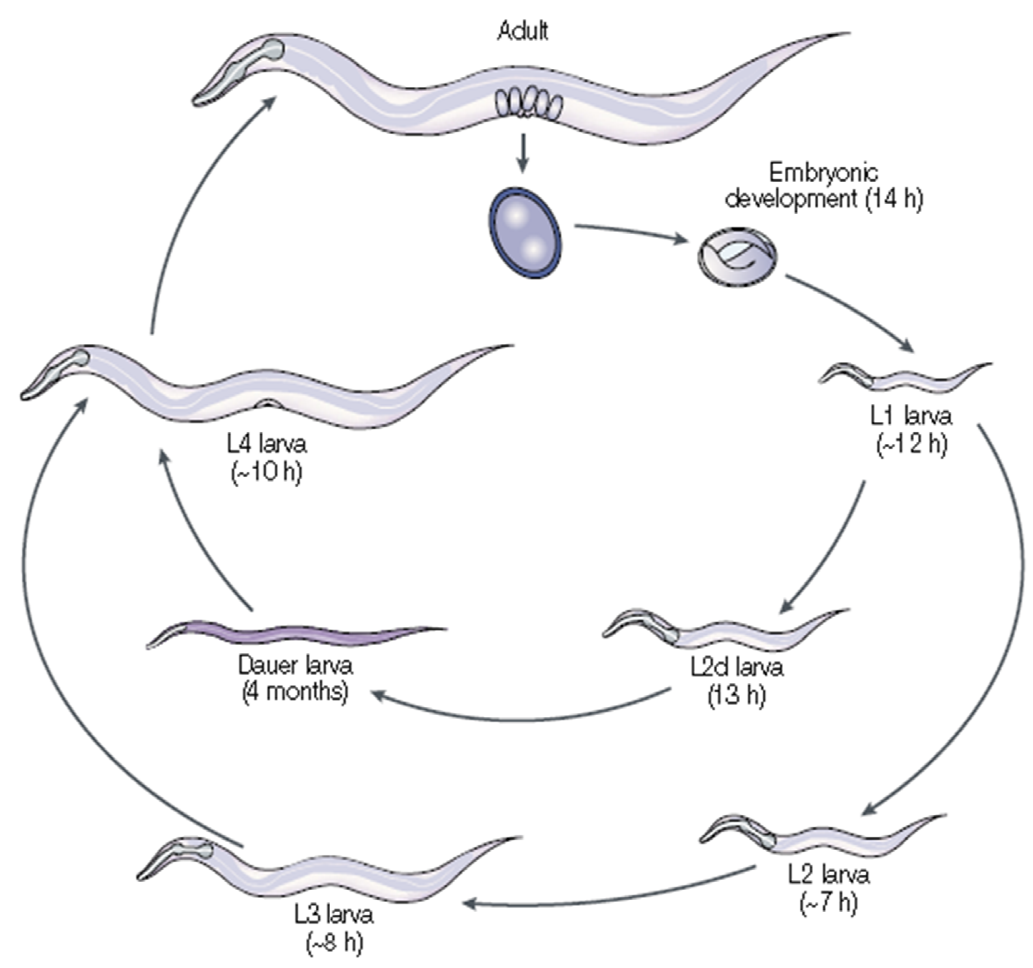

Extraído e modificado de Jorgensen e Mango, 2002

Figura 1.3: Ciclo de vida do nematóide Caenorhabditis elegans. O desenvolvimento se dá por quatro estadios larvais, além de uma forma de resistência (larva Dauer) quando as condições de sobrevivência são desfavoráveiss. O ciclo de vida dura aproximadamente 48 horas a $22^{\circ} \mathrm{C}$ ou 96 horas a $15^{\circ} \mathrm{C}$. Os adultos vivem cerca de 15 dias e depositam até 350 ovos nesse mesmo período.

Segundo, tamanho pequeno (1,5 $\mathrm{mm}$ de comprimento na fase adulta), facilidade de manutenção de populações numerosas e análise sob microscópio eletrônico a fim de desvendar detalhes estruturais (ANKENY, 2001; RIDDLE et al., 1997). Terceiro, facilidade de cultivo em laboratório (culturas monoxênicas alimentadas com E. coli). Quarto, existência de indivíduos hermafroditas protândricos (5 autossomos + XX) e machos (5 autossomos + X0). A população é naturalmente constituída de 99,9\% de hermafroditas e $0,1 \%$ de machos que são gerados espontaneamente pela não-disjunção dos cromossomos sexuais na meiose dos gametas. Quinto, C. elegans selvagem assim como a maioria das linhagens mutantes podem ser congeladas indefinidamente em 
nitrogênio líquido na presença de $15 \%$ (v/v) de glicerol e recuperadas posteriormente. Aproximadamente 35 a $45 \%$ dos animais congelados sobrevivem ao processo de congelamento e descongelamento, sendo que esse número decresce minimamente mesmo após vários anos de estocagem (BRENNER, 1974).

Brenner teve o primeiro contato com $C$. elegans quando recebeu uma cultura da linhagem Bristol de Ellsworth C. Dougherty, que já vinha trabalhando com a espécie desde o final da década de 40 do século passado. Os primeiros estudos de Brenner foram relacionados à genética e ele foi o primeiro a produzir mutantes de C. elegans por exposição ao etilmetanosulfonado (EMS) e em 1974 publicou o artigo "The Genetics of Caenorhabditis elegans" no qual descreve 100 marcadores genéticos morfológicos e comportamentais agrupados em seis cromossomos (BRENNER, 1973; BRENNER, 1974). A eleição de C. elegans como organismo modelo chegou a ser vista inicialmente com incredulidade por alguns pesquisadores, por considerarem o animal apenas "um tubo que se movia para frente e para trás em movimentos sinuosos". Com o passar dos anos, essa visão foi substituída pelo alvoroço da descoberta de outras características ainda mais intrigantes para o estudo da biologia do desenvolvimento: o pequeno e constante número de células somáticas (959 no hermafrodita adulto e 1.031 no macho adulto), a transparência do corpo e a manutenção da posição das células entre os diferentes indivíduos (RIDDLE et al., 1997). Estudos que se seguiram foram responsáveis pela elucidação da linhagem celular (SULSTON et al., 1983; SULSTON et al., 1988). O passo seguinte foi a montagem, a partir de oito mil micrografias eletrônicas seqüenciais, do diagrama de conexões neuronais (WHITE et al., 1986), seguida pelo mapeamento genético de mutações e pelo seqüenciamento total de seu genoma (THE C. ELEGANS SEQUENCING CONSORTIUM, 1998).

As características favoráveis e os avanços no conhecimento da biologia dessa espécie descritos brevemente acima demonstraram, nos últimos 30 anos, um alto grau de conectividade com outras áreas do conhecimento no mesmo organismo ou em organismos distintos (Drosophila, camundongo, células de mamíferos em cultura). Estes aspectos tornaram $C$. elegans um poderoso instrumento também no aprofundamento do conhecimento de nematóides parasitas. A partir daí, estudos inviáveis de serem realizados com espécies de nematóides parasitas devido a fatores éticos e práticos têm utilizado $C$. elegans como modelo (BRITTON e MURRAY, 2006). 
C. elegans possui características únicas que predestinaram este organismo para a visualização dos padrões de expressão gênica através do uso dos genes repórteres da beta-galactosidase (LacZ) (FIRE et al., 1990) e da proteína verde fluorescente (GFP) (CHALFIE et al., 1994). A transparência de C. elegans ao longo de todo desenvolvimento permite a análise microscópica in vivo sem ser necessária a dissecção do animal. Além disso, a pequena espessura dos animais (aproximadamente $75 \mu \mathrm{m}$ de diâmetro numa secção transversal) permite o uso de microscopia de contraste de interferência (Nomarski). Finalmente, técnicas de transformação da linhagem germinativa permitem a rápida geração de animais transgênicos.

O gene LacZ de E. coli, que codifica a $\beta$-galactosidase, foi usado pela primeira vez para estudar a expressão gênica em células individuais de C. elegans em 1990 (FIRE et al., 1990) e foi o gene repórter de escolha até a introdução do GFP em 1994 (CHALFIE et al., 1994). A principal vantagem de GFP sobre LacZ é a capacidade de se visualizar a expressão do gene repórter em animais vivos ao invés de preparações fixadas. Portanto, a GFP pode ser mais facilmente utilizada para uma série de fins incluindo: análise do padrão de expressão, dissecção das sequiências reguladoras em cis, localização de proteínas, visualização da anatomia celular (p.ex. neuroanatomia), identificação de células e visualização de processos celulares e fisiológicos (CHALFIE et al., 1994). Por essas razões, transgenes repórteres de GFP se tornaram um instrumento primário para análise da expressão gênica em C. elegans.

O genoma de C. elegans é muito compacto (aproximadamente $100 \mathrm{Mpb}$ ), equivalente a apenas vinte vezes o genoma de Escherichia coli $(4,6 \mathrm{Mpb})$. A maior parte da informação reguladora em cis fica próxima de diversas quilobases imediatamente a montante do gene. No entanto, há um número crescente de exemplos nos quais foram encontradas sequiências reguladoras em cis dentro de introns (especialmente genes contendo grandes introns) (WENICK e HOBERT, 2004) ou na 3`UTR (WIGHTMAN et al., 1993). Raramente, no entanto, seqüências reguladoras em cis foram encontradas muito distantes (além de genes flanqueadores a montante ou a jusante) do gene de interesse (CONRADT E HORVITZ, 1999; WENICK E HOBERT, 2004).

Os promotores de genes de C. elegans podem ser diferenciados, em teoria, como simples ou complexos (OKKEMA e KRAUSE, 2005). Os primeiros carregam toda a informação necessária para o correto perfil de expressão gênica numa região de não mais que algumas centenas de pares de bases, já os complexos apresentam diversas 
sequências regulatórias dispersas ao longo de uma região mais longa de DNA (OKKEMA e KRAUSE, 2005). Tendo em vista a complexidade estrutural e funcional desses promotores, uma tentativa de gerar o "Promoteroma" de C. elegans foi iniciada em 2004 pelo grupo de Marc Vidal (DUPUY et al., 2004; REECE-HOYES et al., 2007). Esse projeto pretende descrever o padrão de expressão de milhares de genes de $C$. elegans.(DUPUY et al., 2004).

A transcrição controlada espacialmente tem sido amplamente estudada tomando como base o intestino de C. elegans (MADURO e ROTHMAN, 2002). A endoderme é derivada de uma única célula do embrião, célula $\mathrm{E}$, que surge no estágio de três células e sofre divisões até dar origem às 20 células do intestino do adulto (SULSTON et al., 1983) (Figura 1.4). Genes expressos especificamente nessas células, como é o caso das vitelogeninas (VIT), apresentam o motivo GATA na região promotora, reconhecido pelos fatores de transcrição tipo-GATA (SPIETH et al., 1988). Dos onze genes de fatores de transcrição tipo-GATA no genoma de $C$. elegans, cinco deles são expressos especificamente no intestino (END-1 e -3, ELT-2 e -7 e ELT-4) (FUKUSHIGE et al., 1999; ZHU et al., 1997).

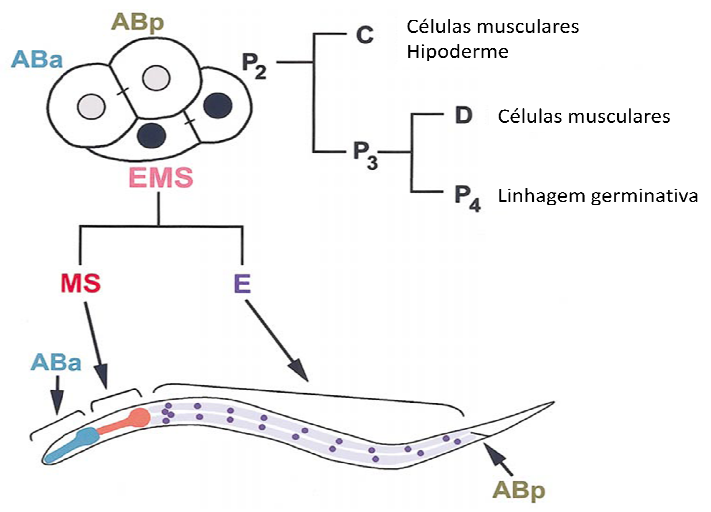

Extraído e modificado de Maduro e Rothman, 2002

Figura 1.4:Diagrama do embrião de $C$. elegans no estágio de quatro células. A célula EMS dá origem ao precursor da endoderme (célula E) e ao precursor da mesoderme (célula MS). O precursor E origina as 20 células que compõem o intestino do nematóide adulto.

\subsection{Interferência de RNA}

Na última década, a função de diversos genes de C. elegans foi identificada por genômica funcional a partir da descoberta do fenômeno de interferência de RNA ou, simplesmente, RNAi (FIRE et al., 1998) (Figura 1.5). 


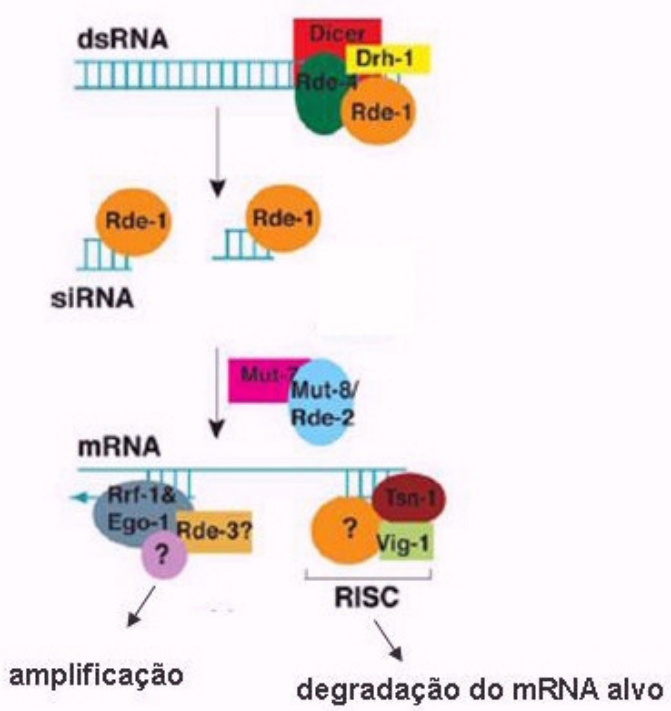

extraído e modificado de Grishok, 2005

Figura 1.5: RNAi em C. elegans. Representação esquemática do mecanismo de RNAi em C. elegans, desde a clivagem de dsRNAs em siRNAs (small interfering RNAs) até a formação do complexo de silenciamento induzido por RNA (RISC) e a produção de novas moléculas de dsRNA (amplificação).

Esse fenômeno ocorre também em outros organismos como insetos (KENNERDELL e CARTHREW, 1998), protozoários (ULLU et al., 2004) e células de mamífero em cultura (HANNON, 2002). Imagina-se que, in vivo, a degradação de moléculas de RNA mensageiro específicas através da ativação de uma via dependente de RNA dupla-fita (dsRNA) tenha um papel na proteção do organismo contra infecções virais e “transposons" (WILKINS et al., 2005).

Em C. elegans, o efeito é sistêmico, espalhando-se para a maior parte das células do organismo quando o dsRNA é introduzido por alimentação (FRASER et al., 2000; KAMATH et al., 2001; TIMMONS et al., 2001), por injeção no pseudoceloma (FIRE et al., 1998) ou por imersão (TABARA et al., 1998; MAEDA et al., 2001). Ainda não é conhecido o sinal de silenciamento que é transportado para as diferentes células e tecidos, mas há indícios que sejam moléculas de RNA dupla-fita, provavelmente siRNAs, que seriam levadas do lúmen intestinal para o interior das células por endocitose (através da proteína receptora SID-2) e levadas ao líquido pseudocelomático através de transporte passivo por um canal de dsRNA, SID-1, de onde podem ser endocitadas por células da linhagem germinativa ou musculares (FEINBERG e HUNTER, 2003; WINSTON et al., 2002). O esquema abaixo (Figura 1.6), modificado de Jose e Hunter (2007), representa um corte transversal de um adulto de C. elegans 
destacando parte da maquinaria molecular que controla a tomada de dsRNA e a distribuição do sinal de silenciamento para as outras células.

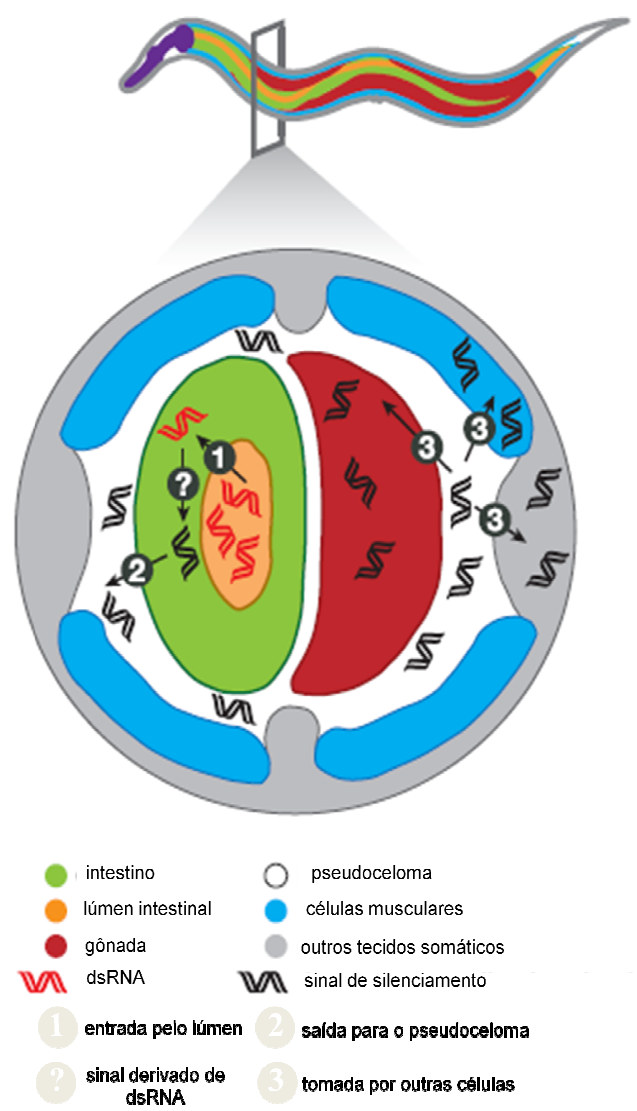

extraído e modificado de Jose e Hunter, 2007

Figura 1.6: Distribuição do sinal de silenciamento. Corte transversal esquemático na porção central de um adulto hermafrodita de $C$. elegans destacando a presença de moléculas de dsRNA na cavidade do tubo digestivo obtidas por alimentação, injeção ou imersão (1), endocitose e transporte passivo através dos enterócitos (2) e a distribuição do sinal de silenciamento para as outras células do organismo (3). Em C. elegans, o silenciamento é sistêmico independentemente da maneira de obtenção das moléculas de dsRNA, afetando todos os tipos celulares, com excecão de neurônios.

O fenômeno da interferência de RNA, ou RNAi, foi descoberto e caracterizado em

C. elegans anos antes de se tornar a ferramenta mais utilizada em estudos de Biologia Celular em outros organismos. Nesse nematóide, RNAi tem características adicionais como ter seu efeito amplificado a partir do sinal de interferência inicial, distribuído sistemicamente e transmitido para gerações seguintes por mecanismos que vêm sendo elucidados recentemente (ALCAZAR et al., 2008). O sinal epigenético responsável pela hereditariedade do efeito que pode persistir além da geração F1 ainda é desconhecido, mas curiosamente é transmitido mais eficientemente através de gametas masculinos (ALCAZAR et al., 2008). 
Em C. elegans, a capacidade do silenciamento ser distribuído pela maioria das células do indivíduo (com exceção dos neurônios) pôde ser mais bem estudada após a caracterização dos mutantes sid (systemic RNAi defective) ou rsd (RNAi spreading defective). O gene sid-1/rsd-8 corresponde a uma proteína transmembrana que facilita a tomada de dsRNA pelas células, provavelmente por endocitose (JOSE e HUNTER, 2007).

A amplificação é dependente do sinal de interferência inicial, assim como de RNA polimerases dependentes de RNA (RRF-1 em tecidos somáticos e EGO-1 em células germinativas) (SIJEN et al., 2001; MAINE et al., 2005; PAK E FIRE, 2007).

Originalmente, os ensaios eram realizados pela injeção de RNA dupla-fita (dsRNA) diretamente na gônada ou no pseudoceloma de C. elegans e os efeitos eram analisados na geração seguinte (FIRE et al., 1998). Pouco tempo depois foram desenvolvidas as metodologias de RNAi por alimentação (FRASER et al., 2000; KAMATH et al., 2001; TIMMONS et al., 2001) e por imersão em solução contendo dsRNA (TABARA et al., 1998; MAEDA et al., 2001), ambas permitindo estudos em grande escala. A primeira metodologia baseia-se no fato de $C$. elegans se alimentar de bactérias. Nematóides submetidos a esse ensaio são alimentados com bactérias expressando dsRNA.

A via de RNAi pode ser dividida em dois estágios: (1) produção de siRNA (small interfering RNA) e (2) silenciamento (knock-down) do gene alvo (Figura 1.7). A primeira fase é realizada por um complexo que contém uma RNAse III específica para dsRNA denominado "DICER" que, juntamente com uma proteína ligadora de RNA (RDE-4), uma helicase (DRH-1) e RDE-1, gera siRNAs e os transfere para o complexo RISC (RNA-Induced Silencing complex) (Figura 1.5).

O complexo ribonucleoprotéico RISC comanda a segunda etapa do fenômeno a partir do momento que é ativado ao receber moléculas de siRNA provavelmente através da proteína RDE-1. O complexo RISC ativado (RISC+siRNA) degrada a molécula de mRNA alvo complementar.

Estudos recentes de RNAi têm sido realizados com nematóides parasitas. Uma vez que genes específicos que controlam etapas do parasitismo não apresentam similaridade com genes de $C$. elegans, tornou-se necessário o desenvolvimento de tecnologia de interferência em espécies parasitas através da imersão em solução contendo dsRNA. Nippostrongylus brasiliensis foi a primeira espécie onde um estudo deste tipo foi realizado (HUSSEIN et al., 2002), seguida de Brugia malayi (ABOOBAKER e 
BLAXTER, 2003), Onchocerca volvulus (FORD et al., 2005) e Ascaris suum (ISLAM et al., 2005).

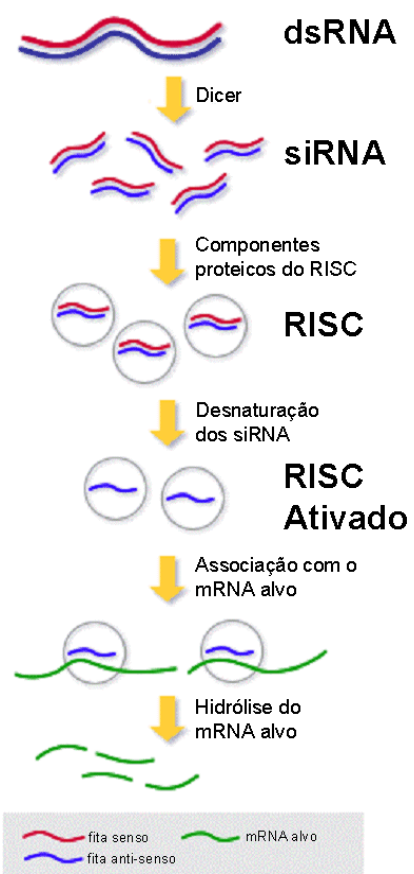

Figura 1.7: A via de RNAi. Destaque para os principais eventos da via de interferência: produção de siRNAs e silenciamento do gene alvo.

As sequências de genes da via de RNAi de C. elegans foram utilizadas para uma busca no genoma de Haemonchus contortus (GELDHOF et al., 2007). Dentre aqueles que apresentaram similaridade com genes de C. elegans estão alguns dos fatores mostrados na figura 1.5. No entanto, genes essenciais à via não foram encontrados nessa análise, como é o caso de $r d e-2, r d e-4$, sid-2 e rsd-2. Se rde-4, rde-2, sid-2 e rsd-2 estiverem realmente ausentes, significa que o efeito da interferência nesse parasita não seria distribuído para os outros tecidos, que o dsRNA não seria processado em siRNAs ou que uma via alternativa estaria presente nessa espécie (GELDHOF et al., 2007).

\subsection{Pró-hormônio convertases}

Muitos peptídeos e hormônios biologicamente ativos dependem da clivagem de seus precursores em um par de aminoácidos básicos numa região não-estruturada do peptídeo - como um domínio alça-beta - para que sejam ativados.

Serino proteases responsáveis por esse tipo de clivagem pós-traducional têm sido isoladas e caracterizadas em diversos organismos desde a identificação da protease 
codificada no gene KEX2 de Saccharomyces cerevisiae (FULLER et al., 1988) também chamada de "kexin". Essas enzimas são conhecidas como SPCs ("Subtilisin-like proprotein convertase"), pró-hormônio convertases (PCs) ou PACEs ("paired aminoacid converting enzime") (STEINER, 1998) e possuem grande similaridade com as subtilisinas bacterianas quanto à estrutura primária do sítio ativo. Mamíferos apresentam sete pró-hormônio convertases: furina, PC1/PC3, PC2, PACE4, PC4, PC5/PC6, PC7/PC8/LPC/SPC7/PQP1 (ROEBROEK et al., 1986; FULLER et al., 1988). A primeira convertase de mamíferos a ter a estrutura tridimensional definida foi a furina (HENRICH, 2003).

As convertases estão envolvidas na regulação de inúmeros processos fisiológicos. Daí a necessidade de se utilizar o termo proteólise limitada para caracterizar a especificidade de atividade dessas enzimas, diferenciando-a da proteólise ao acaso que ocorre numa simples degradação protéica (NEURATH, 1999).

A estrutura básica das convertases inclui, além do peptídeo sinal, um pró-domínio que atua como chaperonina intramolecular assim como inibidor (SHINDE et al., 1993; ANDERSON et al., 1997; ELLIS, 1998; THACKER E ROSE, 2000). O sítio ativo é muito semelhante ao da subtilisina bacteriana e é seguido por um domínio $\mathrm{P}$ extremamente conservado e importante na regulação da atividade catalítica (igura 1.8) (ZHOU et al., 1998; BARALE et al., 1999).

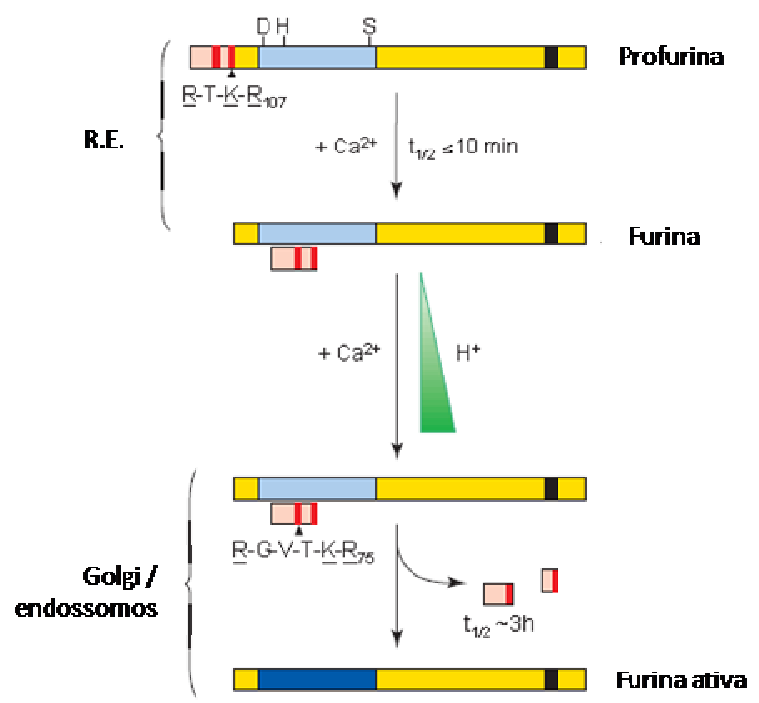

Extraído e modificado de Molloy et al., 1999

Figura 1.8:Modelo de ativação in vivo da furina. O pró-domínio é clivado após participar como chaperonina no "folding" do zimógeno. O pró-domínio permanece complexado à enzima através de pontes dissulfeto, atuando como inibidor in cis. Com a acidificação do compartimento após o transporte para o Golgi, ocorre um segundo evento catalítico in trans que libera o domínio catalítico e a enzima está ativa para clivagem de substratos. Rosa = pródomínio; Vermelho = sítios de clivagem autocatalítica; Azul = domínio catalítico; Preto = domínio transmembrana; R.E = retículo endoplasmático. 
As convertases foram agrupadas na subfamília S8B do clã SB (BARRET e RAWLINGS, 1995; BARRETT et al., 1998) devido à ordem da tríade catalítica (AspHis-Ser), presença de $\alpha$-hélices e folhas- $\beta$ na estrutura secundária e por clivarem substratos em pares de aminoácidos básicos,

As convertases são distribuidas pela via secretória constitutiva e regulada para os seus diferentes destinos: superfície celular, endossomos, lisossomos e grânulos de secreção (MOLLOY et al., 1999; THOMAS, 2002).

A atividade catalítica durante o tráfego pela via secretória é inibida pelo pró-domínio que, após uma primeira clivagem autocatalítica, se mantém ligado não-covalentemente ao sítio ativo da enzima, bloqueando o acesso aos substratos. Essa inibição cessa somente quando a enzima atinge regiões do complexo de Golgi onde o $\mathrm{pH}$ é mais baixo e a concentração de cálcio é mais alta, levando a uma segunda clivagem autocatalítica em uma porção mais central do pró-domínio (YABUTA et al., 2001).

\subsubsection{Pró-hormônio convertases recombinantes}

Desde a década de 90, convertases recombinantes de diferentes animais têm sido expressas em sistemas heterólogos conservando sua atividade proteolítica e permitindo, assim, sua caracterização visto que, normalmente, convertases estão presentes nas células em baixíssimas concentrações dificultando ou impossibilitando sua purificação a partir de homogeneizados.

O estudo das convertases recombinantes de humanos tem revelado seu envolvimento em inúmeros processos patológicos, principalmente infecções virais, câncer e até doenças neurodegenerativas como o mal de Alzheimer (FUGÈRE e DAY, 2005). Furina, PC5 e PC7 são convertases responsáveis pela ativação do fator de crescimento endotelial C (VEGF-C), indutor do crescimento de tumores (SIEGFRIED et al., 2003). Formas recombinantes permitiram a caracterização dos possíveis substratos de PC2 humana (FAHNESTOCK e ZHU, 1999) e também da furina, que mostrou ativar moléculas de adesão envolvidas com a supressão de tumores, como a caderina (POSTHAUS et al. 1998).

A convertase humana PC2 recombinante permitiu a caracterização dos seus possíveis substratos (FAHNESTOCK e ZHU, 1999). Também de humanos, a furina pôde ser caracterizada através da produção da recombinante como sendo uma das convertases 
responsáveis pelo processamento de moléculas de adesão que podem estar envolvidas com a supressão de tumores, como a caderina (POSTHAUS et al., 1998).

Foi realizado um estudo estrutural da furina humana no qual alguns mutantes que tiveram um dos seis resíduos altamente conservados modificado, são letais por afetarem o sítio S6 da convertase (SIEZEN et al., 1994) que é o provável responsável pela ligação dessa ao resíduo P6 do substrato sendo essencial à atividade endoproteolítica (TAKAHASHI et al., 1994).

Sua importância em processos fisiológicos da interação do parasita com seu hospedeiro já é conhecida e, por isso, são consideradas possíveis alvos para o desenvolvimento de drogas antiparasitárias (FUGÈRE e DAY, 2005). Como exemplo de convertases de parasitas, foram identificadas, caracterizadas e expressas as convertases PfSUB-1 e PfSUB-2 de Plasmodium falciparum que são indispensáveis para o último passo do processamento da MSP1 ("merozoite surface protein 1"), proteína responsável pela invasão dos eritrócitos pelo parasita (BARALE et al., 1999). Todos os membros do Filo Apicomplexa cujos genomas já foram seqüenciados apresentam genes de proteases tipo subtilisina como, por exemplo, o gene da convertase TgSUB2 de Toxoplasma gondii (MILLER et al., 2003). Outro fato comum entre esses parasitas é o processamento pós-traducional do conteúdo protéico das róptrias, organelas diretamente envolvidas na secreção de agentes que auxiliam na invasão da célula do hospedeiro. Tendo em vista esses fatores, as convertases foram consideradas novos alvos para produção de drogas antiparasitárias (MILLER et al., 2003).

No parasita Onchocerca volvulus, a convertase codificada no gene bli-4, blisterase, envolvida no processamento do colágeno que forma a cutícula desse nematóide foi caracterizada através da forma recombinante. O inibidor suicida decanoil-RVKRclorometilcetona, identificado em 1995 como inibidor da furina humana pelo grupo de Richard Leduc, Canadá (DENAULT et al., 1995), mostrou-se eficiente na inibição da blisterase na escala de nM (POOLE et al., 2003). Esse inibidor apresenta uma característica particular devido à cauda hidrofóbica (decanoil) que permite sua entrada na célula promovendo a inibição da convertase in vivo (DENAULT et al., 1995).

\subsubsection{Pró-hormônio convertases de $C$. elegans}

O genoma do nematóide de vida livre Caenorhabditis elegans apresenta quatro genes de convertases identificados pelo trabalho do "The C. elegans sequencing consortium" 
(THE C. ELEGANS SEQUENCING CONSORTIUM, 1998). Esses genes ( $k p c-1, k p c-2$, $k p c-3, k p c-4)$ codificam quatorze enzimas que estão compreendidas na família das KPCs (Kex2/subtilisin-like proprotein convertases). O maior número de enzimas devese ao "splicing" alternativo desses genes (THACKER e ROSE, 2000). Esse nematóide oferece facilidades para o estudo da distribuição da atividade e regulação dessas proteases por ser um animal simples, ter sua linhagem celular totalmente mapeada e genoma mitocondrial e nuclear completamente seqüenciados (THE C. ELEGANS SEQUENCING CONSORTIUM, 1998). Recentemente foi discutido em detalhe o envolvimento das convertases na biogênese da cutícula de nematóides (PAGE e WINTER, 2003).

Os genes $k p c-1, k p c-3$ e $k p c-4$ de $C$. elegans estão localizados no cromossomo I e o gene $k p c-2$ está localizado no cromossomo X. Já foi demonstrado em C. elegans que a degradação dos mRNAs desse gene por interferência de RNA gera animais com movimentação descoordenada e crescimento retardado (THACKER et al., 2000).

A estrutura típica das convertases de $C$. elegans é muito semelhante à das convertases de mamíferos (Figura 1.9).

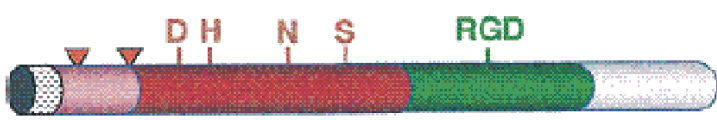

\begin{tabular}{|c|c|}
\hline की & Pep tideo sinal \\
\hline & Pró-domínio \\
\hline & Dominio catalitico \\
\hline & Dominio P \\
\hline$\therefore$ & C-terminal \\
\hline$\nabla$ & Sitios auto-catal \\
\hline
\end{tabular}

Extraído e modificado de Thacker e Rose, 2000

Figura 1.9:Diagrama representativo da estrutura típica de uma KPC (kex2/subtilisin-like proprotein convertase) de $C$. elegans.

A elucidação de todos os substratos das convertases de $C$. elegans poderá futuramente definir as convertases como alvos terapêuticos. 


\subsubsection{O gene $k p c-1$}

O gene $k p c-1$ foi superficialmente analisado até o momento e nenhum substrato para a enzima foi identificado até o momento. No entanto, Thacker (comunição pessoal) prevê como prováveis substratos os precursores de TGF- $\beta$ codificados nos genes $d a f-7$, $d b l-1$ e unc-129. É a convertase mais similar à convertase de vitelogenina de Aedes aegypti, AeVC (CHEN e RAIKHEL, 1996; WINTER, 2002).

\subsubsection{O gene $k p c-2 / e g l-3$}

Mutantes egl (egg-laying deficient) apresentam deficiência na postura de ovos por diferentes causas: má-formação da vulva, defeitos na estrutura e/ou função da musculatura responsável pela abertura da vulva ou defeitos no circuito neuronal que controla a postura de ovos, esses defeitos tendo sido caracterizados por Trent (1983).

Em 1994 foi descrita uma atividade em C. elegans similar à atividade da convertase PC2 de mamíferos que recebeu o nome de CELPC 2 (GÓMEZ-SALADÍN et al., 1994; GÓMEZ-SALADÍN et al., 1997). Atualmente CELPC2 é denominada KPC-2/EGL-3 (THACKER e ROSE, 2000). PC2 de mamíferos é responsável pelo procesamento de neuropeptídeos. O alto grau de similaridade entre KPC-2/EGL-3 e PC2, além da expressão de KPC-2/EGL-3 em neurônios de C. elegans, esta enzima foi implicada no processamento pós-traducional de neuropeptídeos (KASS et al., 2001). Na análise experimental do processamento de peptídeos tipo FMRFamida e neuropeptídeos tipo insulina em mutantes das diferentes convertases de C. elegans, os mutantes kpc-2/egl-3 apresentaram o perfil de processamento mais alterado (HUSSON et al., 2006). Em 2001, outro grupo de pesquisadores mostrou que essa convertase, codificada no gene $k p c-2 /$ egl-3, estava envolvida com respostas mecanosensoriais, mais especificamente à sensitividade ao toque na região anterior, além de apresentar o fenótipo egl (KASS et al., 2001).

\subsubsection{O gene $k p c-3 / a e x-5$}

A convertase KPC-3/AEX-5 participa da regulação dos ciclos de defecação. Mutantes desse gene apresentam defeitos na etapa "Exp" (contração dos músculos 
entéricos e expulsão do conteúdo inestinal) e são constipados. Inicialmente, cogitava-se que a expressão dessa convertase se desse em tecidos nervosos, já que o processo de defecação é controlado por neurônios que respondem a GABA, além do fato dessa convertase poder também estar envolvida no processamento de outros neuropeptídeos (THOMAS, 1990; MCINTIRE et al., 1993).

Recentemente foi verificado, através da produção de nematóides transgênicos contendo o gene kpc-3/aex-5 fusionado a GFP sob controle do promotor específico de enterócitos Pvha-6 que KPC-3/AEX-5 é expressa nos enterócitos, sendo secretada e tomada por celomócitos (MAHONEY et al., 2008). Este padrão de expressão é capaz de recuperar o fenótipo exp. O gene $k p c$-3/aex-5 está presente a jusante do gene de miosina unc-54 num operon e era previsto que sua expressão ocorresse também em células musculares (REINER et al., 1995; THACKER e ROSE, 2000). No trabalho de Mahoney et al. (2008), transgênicos produzidos com construções contendo kpc-3/aex-5 dirigidas às células musculares, não têm o fenótipo exp recuperado, descartando a hipótese de expressão nesse tipo celular.

\subsubsection{O gene $k p c-4 / b l i-4$}

O gene $k p c-4 / b l i-4$ codifica a convertase conhecida como blisterase e tem sido estudado em detalhe. A blisterase está envolvida no processamento pós-traducional de colágenos da cutícula do nematóide e é expressa ao longo de toda a vida de C. elegans. Nematóides mutantes para esse gene apresentam o fenótipo "blistered" (bli), que se caracteriza pelo preenchimento com líquido das cavidades entre as camadas da cutícula, e muitos são letais ainda durante a embriogênese (PETERS et al., 1991). O mesmo grupo mostrou que o gene $k p c-4 / b l i-4$ origina nove isoformas por "splicing" alternativo que diferem entre si pela porção C-terminal. A única mutação viável desse gene, uma deleção de 3.325pb (e937) afeta apenas as isoformas (KPC-4/BLI-4A, E, F, G, H). Uma dessas isoformas deve participar da formação correta da cutícula através do processamento pós-traducional do colágeno (THACKER et al., 1995). Há evidências de que os colágenos sofrem clivagem em motivos de aminoácidos básicos (dados revisados em GUPTA et al., 1997). 


\subsection{Vitelogênese}

Embriões de animais ovíparos têm no vitelo o estoque de nutrientes necessários para seu desenvolvimento (SAPPINGTON et al., 2002). Nesses animais, a vitelogenina (VTG) é o precursor das proteínas de vitelo (YP, yolk polypeptides) (WAHLI et al., 1981). A VTG está envolvida no transporte de lipídeos e íons metálicos para o interior dos ovócitos e atua como reservatório de aminoácidos, fosfato, carboidratos (em vertebrados e insetos), hormônios e vitaminas (BYRNE et al., 1989; DHADIALLA E RAIKHEL, 1990; SAPPINGTON et al., 2002).

As vitelogeninas são lipoproteínas diméricas (WINTER, 2002) de alta densidade (VHDL, very high-density lipoprotein) e de alto peso molecular (200 a 500KDa), conservada em todos os animais ovíparos (WINTER, 2002; SAPPINGTON et al., 2002). São sintetizadas em tecidos ovarianos e/ou extra-ovarianos (hepatopâncreas e ovário nos crustáceos, hemolinfa nos insetos, fígado nos vertebrados e intestino nos nematóides). Foi encontrada síntese de VTG também no ovário do carrapato Rhodnius prolixus (MELO et al., 2000).

As VTGs são codificadas numa pequena família multigênica bastante conservada (BYRNE et al.; 1989; CHEN et al.; 1997; WANG et al., 2000). Genes de VTG foram isolados e sequenciados em nematóides (WINTER et al., 1996; WINTER, 2002), insetos (TELFER, 2002), anfíbios (GEREBR-HUBER et al., 1987), aves (VAN HET SCHIP et al., 1987) e peixes (HIRAMATSU et al., 2002).

Através de estudos de filogenia e estrutura, essas proteínas passaram a pertencer à superfamília das LLTPs ("large lipid transfer proteins") e foram subdivididas na família das LLTPs-tipo vitelogenina que inclui vitelogeninas de vertebrados e de invertebrados, exceto crustáceos (SMOLENAARS et al., 2007).

\subsubsection{Vitelogênese de $C$. elegans}

O padrão das VTGs de Caenorhabditis elegans é relativamente distinto daquele encontrado em outros animais ovíparos. As vitelogeninas desse nematóide são codificadas numa família de seis genes (vit-1 a vit-6) (BLUMENTHAL et al., 1984; SPIETH e BLUMENTHAL, 1985). Cinco desses genes apresentam alto grau de similaridade (vit-1 a vit-5, localizados no cromossomo X), sendo que o gene vit-6 é o mais distante evolutivamente e está localizado no cromossomo IV (WINTER et al., 
1996). Esses seis genes codificam quatro polipeptídeos e são eles YP170A, YP170B, YP88 e YP115. Os genes vit-1 e vit-2 codificam YP170B, vit-3, vit-4 e vit-5 codificam YP170A e vit-6 codifica os polipeptídeos YP88 e YP115 (SHARROCK, 1984; BLUMENTHAL et al., 1984). Todos os genes são expressos no intestino e os polipeptídeos são secretados no pseudoceloma e endocitados pelos ovócitos. Em $C$. elegans, CE-VIT-6, precursor das vitelogeninas YP115 e YP88, é clivado póstraducionalmente no pseudoceloma do animal, o que não ocorre com os polipeptídeos YP170A e YP170B (KIMBLE e SHARROCK, 1983; SHARROCK, 1984; SPIETH et al., 1985) (Figura 1.10).

Esses quatro polipeptídeos (YP170A, YP170B, YP88 e YP115) compõem dois complexos distintos dentro dos grânulos de vitelo: O dímero $\mathrm{B}$ composto por duas subunidades de YP170B e o heterotrímero A que contém YP170A, YP88 e YP115 (SHARROCK et al., 1989) (Figura 1.10).

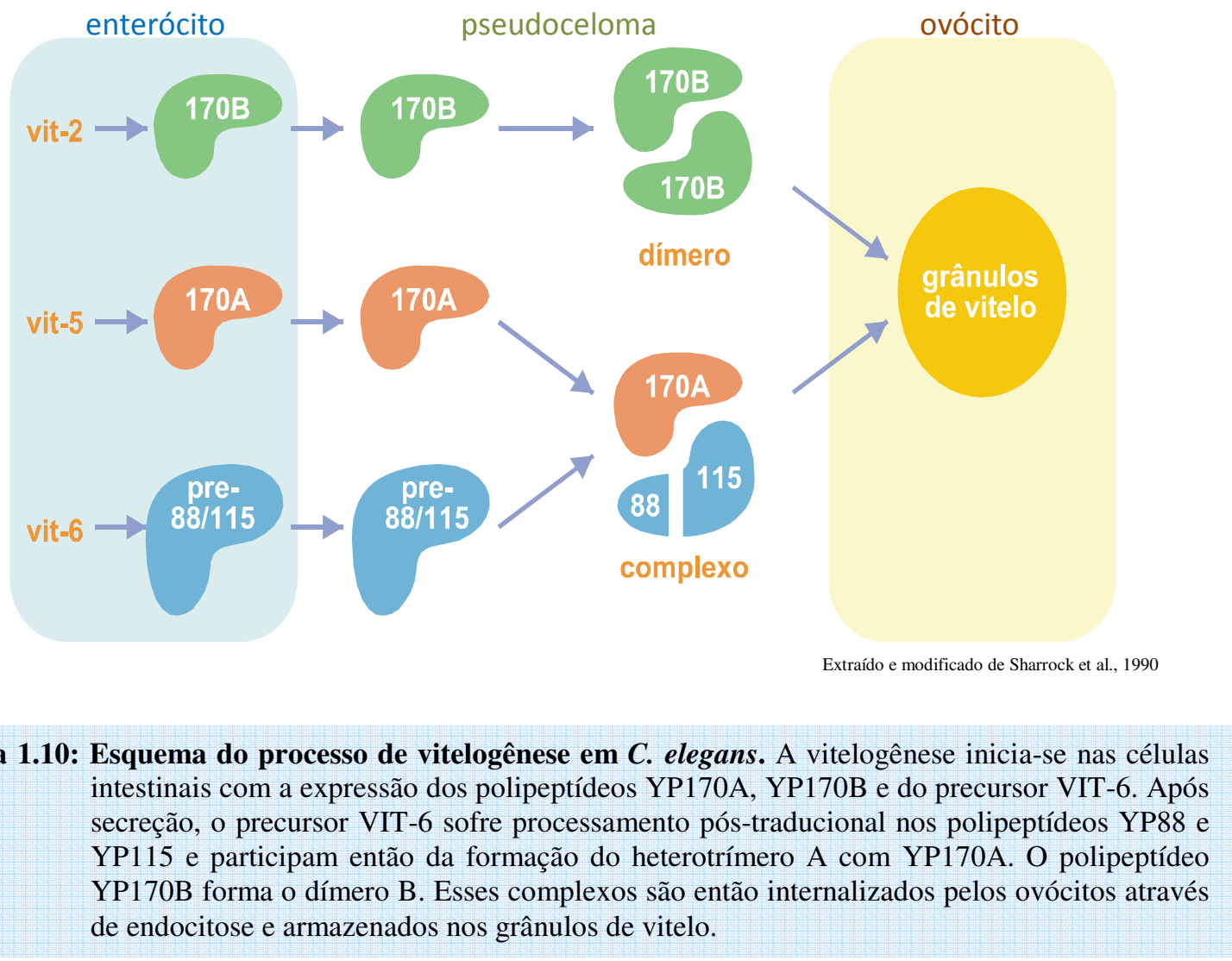

Diversas vitelogeninas são processadas proteoliticamente, como ocorre com CEVIT-6, que origina as subunidades YP115 e YP88. O mesmo pode ser notado no caso 
de OT-VIT-6, uma das vitelogeninas de Oscheius tipulae,cujo processamento origina os polipeptídeos VT2 e VT3 (WINTER, 2002).

Na região do processamento das vitelinas CE-VIT-6 e OT-VIT-6 está presente o par de aminoácidos básicos K-R, o que sugere que processamento ocorra através de uma ou mais convertases. Até o momento não se têm dados sobre a existência de genes de convertases tipo KPC no genoma de Oscheius tipulae (WINTER et al., 1996).

\subsubsection{Vitelogênese e Pró-hormônio convertases}

Uma endoprotease de C. elegans, CelfurPC recentemente renomeada como KPC-1, ainda não está caracterizada bioquimicamente (GÓMEZ-SALADÍN et al., 1997 e THACKER e ROSE, 2000). Essa proteína está codificada no gene F11A6.1 (kpc-l) do cosmídeo F11A6 que consta no banco de dados de $C$. elegans e seu sítio ativo é muito similar ao da convertase de vitelogenina de Aedes aegypti (CHEN e RAIKHEL, 1996; WINTER, 2002). O "splicing" alternativo desse gene provavelmente dá origem a duas formas: F11A6.1a e F11A6.1b, correspondentes às convertases KPC-1A e KPC-1B, respectivamente. KPC-1B possuiria uma inserção na porção C-terminal, diferentemente de KPC-1A. Formas de "splicing" sexo-específicas foram identificadas no gene de furina de Dirofilaria immitis, um nematóide parasita (JIN et al., 1999).

Algumas vitelogeninas originam-se do processamento proteolítico de seus precursores (CHEN e RAIKHEL, 1996). Em C. elegans, CE-VIT-6, precursor das vitelogeninas YP115 e YP88, é clivado logo após um par de aminoácidos básicos sugerindo um processamento por convertase, o que não ocorre com as vitelogeninas codificadas nos genes vit-2 e vit-5.

O mesmo motivo de aminoácidos básicos pode ser notado na região de processamento de CEW1-VIT-6 de outro nematóide - Oscheius tipulae (linhagem CEW1) - gerando as vitelinas VT2 e VT3. Até o momento não existem dados sobre genes de convertases tipo subtilisina no genoma de CEW1. 


\section{Conclusões}


1. Foram produzidos anticorpos a partir dos polipeptídeos recombinantes P20N e P20C capazes de reconhecer, respectivamente, YP88 e YP115. Esses anticorpos foram capazes de diferenciar o precursor de vitelogenina VIT-6 dos produtos do processamento YP88 e YP115;

2. Regiões promotoras putativas do gene $k p c-1$ dirigiram a expressão do gene repórter da GFP em neurônios ASH, RIM, células do intestino porterior, células musculares e hipoderme;

3. Nenhuma das convertases de $C$. elegans é exclusivamente responsável pelo processamento de VIT-6, podendo existir sobreposição de atividade entre elas e/ou atividades complementares;

4. KPC-2/EGL-3 e KPC-3/AEX-5 são as convertases mais prováveis de atuarem com ou no lugar de KPC-1 no processamento de VIT-6, fato corroborado pela colocalização das enzimas nos enterócitos e pelo processamento incompleto do precursor VIT-6 em ensaios de RNAi combinado;

5. KPC-1 recombinante produzida em sistema procarionte sofre processamento póstraducional no motivo de aminoácidos básicos (KR) entre o pró-domínio e o domínio catalítico;

6. Todos os mutantes de $C$. elegans utilizados neste trabalho são susceptíveis ao efeito de RNAi administrado via alimentação;

7. O ensaio de RNAi combinado, desenvolvido neste trabalho, mostrou ser útil na análise de redundância funcional entre pró-hormônio convertases de C. elegans. 
Referências bibliográficas* 
ABOOBAKER, A.A.; BLAXTER, M.L. Use of RNA interference to investigate gene function in the human filarial nematode parasite Brugia malayi. Molecular and Biochemical Parasitology, v. 129, p. 41-51, 2003.

ALCAZAR, R.M.; LIN, R.; FIRE, A.Z. Transmission dynamics of heritable silencing induced by Doublestranded RNA in Caenorhabditis elegans. Genetics, v. 180, n. 3, p. 1275-1288, 2008.

ANDERSON, E.D.; VANSLYKE, J.K.; THULIN, G.D.; JEAN, F.; THOMAS, G. Activation of the furin endoprotease is a multiple-step process: requirements for acidification and internal propeptide cleavage. The EMBO Journal, v. 16, n. 7, p. 1508-1518, 1997.

ANKENY, R.A. The natural history of Caenorhabditis elegans research. Nature Reviews Genetics, v. 2, p. 474-479, 2001.

BARALE, J. C.; BLISNICK, T.; FUJIOKA, H.; ALZARI, P.M.; AIKAWA, M.; BRAUN-BRETON,C.; LANGSLEY, G. Plasmodium falciparum subtilisin-like protease 2, a merozoite candidate for the merozoite surface protein 1-42 maturase. Proceedings of the National Academy of Sciences of the United States of America, v. 96, p. 6445-6450, 1999.

BARRETT, A. J.; RAWLINGS, N. D. Families and clans of serine peptidases. Archives of Biochemistry and Biophysics, v. 318, p. 247-250, 1995.

BARRETT, A. J.; RAWLINGS, N. D.; WOESSNER, J. F. Handbook of Proteolytic Enzymes. Miami: Academic Press, 1998. 2368 p.

BARSTEAD, R. J.; KLEIMAN, L.; WATERSTON, R. H. Cloning, sequencing and mapping of an alpha-actinin gene from the nematode Caenorhabditis elegans. Cell Motility and the Cytosol., v. 20, n. 1, p. 69-78, 1991.

BEANAN, M.J.; STROME, S. Characterization of a germ-line proliferation mutation in C. elegans. Development, v. 116, p. 755-766, 1992.

BENIAN, G.M.; KIFF, J.E.; NECKELMANN, N.; MOERMAN, D.G.; WATERSTON, R.H. Sequence of an unusually large protein implicated in regulation of myosin activity in C. elegans. Nature, v. 342, p. 45-50, 1989.

BENIAN, G.M.; L'HERNAULT, S.W.; MORRIS, M.E. Additional sequence complexity in the muscle gene, unc-22, and its encoded protein, twitchi, of Caenorhabditis elegans. Genetics, v. 134, p. 1097-1104, 1993.

BLAXTER, M. L. Nematoda: genes, genomes and the evolution of parasitism. Advances in Parasitology, v. 54, p. 101-195, 2003.

BLAXTER, M.L.; DE LEY, P.; GAREY, J.R.; LIU, L.X.; SCHELDEMAN, P.; VIERSTRAETE, A.; VANFLETEREN, J.R.; MACKEY, L.Y.; DORRIS, M.; FRISSE, L.M.; VIDA, J.T.; THOMAS, W.K. A molecular evolutionary framework for the phylum Nematoda. Nature, v. 392, n. 6671, p. 71-75, 1998.

BLUMENTHAL, T.; SQUIRE, M.; KIRTLAND, S.; CANE, J.; DONEGAN, M.; SPIETH, J.; SHARROCK, W. Cloning of yolk protein gene family from Caenorhabditis elegans. Journal of Molecular Biology, v. 174, p. 118, 1984.

BOUDREAULT, A.; GAUTHIER, D.; LAZURE, C. Proprotein convertase PC1/3-related peptides are potent slow tight-binding inhibitors of murine PC1/3 and Hfurin. Journal of Biological Chemistry, v. 273, n. 47, p. 31574-31580, 1998.

BRENNER, S. The genetics of behavior. British Medical Bulletin, v. 29, p. 269-271, 1973.

BRENNER, S. The genetics of Caenorhabditis elegans. Genetics, v. 77, n. 1, p. 71-94, 1974.

BRITTON, C.; MURRAY, L. Using Caenorhabditis elegans for functional analysis of genes of parasitic nematodes. International Journal for Parasitology, v. 36, p. 651-659, 2006.

BYERLY, L.; CASSADA, R.C.; RUSSELL, R.L. The life cycle of the nematode Caenorhabditis elegans: I. Wild-type growth and reproduction. Developmental Biology, v. 51, n. 1, p. 23-33, 1976.

BYRNE, B.M.; GRUBER, M.; AB, G. The evolution of egg yolk proteins. Progress in Biophysics and Molecular Biology, v. 53, p. 33-69, 1989.

CHALFIE, M.; TU, Y.; EUSKIRCHEN G.; WARD, W.W.; PRASHER, D.C. Green fluorescent protein as a marker for gene expression. Science, v. 263, p. 802-805, 1994.

*De acordo com:

ASSOCIAÇÃO BRASILEIRA DE NORMAS TÉCNICAS. NBR 6023: Informação e documentação: referências: elaboração. Rio de Janeiro, 2002 
CHEN, J.S.; RAIKHEL, A.S. Subunit cleavage of mosquito pro-vitellogenin by a subtilisin-like convertase. Proceedings of the National Academy of Sciences of the United States of America, v. 93, p. 6186-6190, 1996.

CHEN, J.S.; CHO, W.L.; RAIKHEL, A.S. Analysis of mosquito vitellogenin cDNA. Similarity with vertebrate phosvitins and arthropod serum proteins. Journal of Molecular Biology, v. 237, p. 641-647, 1994.

CHEN, J.S.; SAPPINGTON, T.W.; RAIKHEL, A.S. Extensive sequence conservation among insect, nematode, and vertebrate vitellogenins reveals ancient common ancestry. Journal of Molecular Evolution, v. 44, p. 440451, 1997.

CHIARAMONTE, R.; BASILE, A.; TASSI, E.; CALZAVARA, E.; CECCHINATO, V.; ROSSI, V.; BIONDI, A.; COMI, P. A wide role for NOTCH1 signaling in acute leukemia. Cancer Letters, v. 219, p. 113-120, 2005.

CHIRGWIN, J.M.; PRZYBYLA, A.E.; MACDONALD, R.J.; RUTTER, W.J. Isolation of biologically active ribonucleic acid from sources enriched in ribonuclease. Biochemistry, v. 18, n. 24, p. 5294-99, 1979.

CONRADT, B.; HORVITZ, H.R. The TRA-1A sex determination protein of $C$. elegans regulates sexually dimorphic cell deaths by repressing the egl-1 cell death activator gene. Cell, v. 98, p. 317-327, 1999.

DASGUPTA, S.; FERNANDEZ, L.; KAMEYAMA, L.; INADA, T.; NAKAMURA, Y.; PAPPAS, A.; COURT, D.L. Genetic uncoupling of the dsRNA-binding and RNA cleavage activities of the Escherichia coli endoribonuclease RNase III - the effect od dsRNA binding on gene expression. Molecular Microbiology, v. 28, n. 3, p. 629-640, 1998.

DAVIS, M.W.; BIRNIE, A.J.; CHAN, A.C.; PAGE, A.P.; JORGENSEN, E.M. A conserved metalloprotease mediates ecdisys in Caenorhabditis elegans. Development, v. 131, p. 6001-6008, 2004.

DE LEY, P. A quick tour of nematode diversity and the backbone of nematode phylogeny. In: WormBook. ed. The C. elegans Research Community, 2006. p. 1-8.

DE LEY, P.; BLAXTER, M. L. Systematic position and phylogeny. In: The Biology of Nematodes. Harwood Academic Publishers, 2002.

DENAULT, J-B.; CLAING, A.; D’ORLEANS-JUSTE, P.; SAWAMURA, T.; KIDO, T.; MASAKI, T.; LEDUC, R. Processing of proendothelin-1 by human furin convertase. Federation of European Biochemical Societies Letters, v. 362, p. 276-280, 1995.

DHADIALLA, T.S.; RAIKHEL, A.S. Biosynthesis of mosquito vitellogenin. Journal of Biological Chemistry, v. 265, p. 9924-9933, 1990.

DOUGHERTY, E.S.; HANSEN, E.L.; NICHOLAS, W.L.; MOLLETT, J.H.; YARWOOD, E.A. Axenic cultivation of Caenorhabditis elegans (Nematode: Rhabditidae) with supplemented and unsupplemented chemically defined media. Annals of the New York Academy of Sciences, v. 77, p. 176-217, 1959.

DUCKERT, P.; BRUNAK, S.; BLOM, N. Prediction of proprotein convertase cleavage sites. Protein Engineering, Design and Selection, v. 17, p. 107-112, 2004.

DUPUY, D.; LI, Q.R.; DEPLANCKE, B.; BOXEM, M.; HAO, T. LAMESCH, P.; SEQUERRA, R.; BOSAK, S.; DOUCETTE-STAMM, L.; HOPE, I.A.; HILL, D.E.; WALHOUT, A.J.; VIDAL, M. A first version of the Caenorhabditis elegans Promoterome. Genome Research, v. 14, n. 10B, p. 2169-2175, 2004.

DUPUY, D.; BERTIN, N.; HIDALGO C.A.; VENKATESAN, K.; TU, D.; LEE, D.; ROSENBERG, J.; SVRZIKAPA, N.; BLANC, A.; CARNEC, A.; CARVUNIS, A.R.; PULAK, R.; SHINGLES, J.; REECEHOYES, J.; HUNT-NEWBURY, R.; VIVEIROS, R.; MOHLER, W.A.; TASAN, M.; ROTH, F.P.; LE PEUCH, C.; HOPE I.A.; JOHNSEN, R.; MOERMAN, D.G.; BARABÁSI, A.L.; BAILLIE, D.; VIDAL, M. Genomescale analysis of in vivo spatiotemporal promoter activity in Caenorhabditis elegans. Nature Biotechnology, v. 25, n. 6, p. 663-668, 2007.

DUSENBERY, D.B.; SHERIDAN, R.E.; RUSSELL, R.L. Chemotaxis-defective mutants of the nematode Caenorhabditis elegans. Genetics, v. 80, n. 2, p. 297-309, 1975.

ELLIS, R.J. Steric chaperones. Trends in Biochemical Sciences, v. 23, n. 2, p. 43-45, 1998.

ENTCHEV, E.V.; KURZCHALIA, T.V. Requirement of sterols in the life cycle of the nematode Caenorhabditis elegans. Seminars in Cell and Developmental Biology, v. 16, p. 175-182, 2005.

FAHNESTOCK, M.; ZHU, W. Expression of human prohormone convertase PC2 in a baculovirus-insect cell system. DNA and Cell Biology, v. 18, n. 5, p. 409-17, 1999. 
FARES, H.; GREENWALD, I. Genetic analysis of endocytosis in Caenorhabditis elegans: coelomocyte uptake defective mutants. Genetics, v. 159, p. 133-145, 2001.

FEINBERG, E.H.; HUNTER, C.P. Transport of dsRNA into cells by the transmembrane protein SID-1. Science, v. 301, p. 1545-1547, 2003.

FIRE, A., HARRISON, S.W.; DIXON D. A modular set of lacZ fusion vectors for studying gene expression in Caenorhabditis elegans. Gene, v. 93, p. 189-198, 1990.

FIRE, A.; XU, S.; MONTGOMERY, M. K.; KOSTAS, S. A.; DRIVER, S. A.; MELLO, C. C. Potent and specific genetic interference by double-stranded RNA in Caenorhabditis elegans. Nature, v. 391, p. 806-811, 1998.

FORD, L.; GIULIANO, D.B.; OKSOV, Y.; DEBNATH, A.K.; LIU, J.; WILLIAMS, S.A., BLAXTER, M.L.; LUSTIGMAN, S. Characterization of a novel filarial serine protease inhibitor, Ov-SPI-1, from Onchocerca volvulus, with potential multifunctional roles during development of the parasite. Journal of Biological Chemistry, v. 280, p. 40845-40856, 2005.

FRAND, A.R.; RUSSEL, S.; RUVKUN, G. Functional genomic analysis of C. elegans molting. PLOS Biology, v. 3, n. 10, 2005.

FRASER, A.G.; KAMATH, R.S.; ZIPPERLEN, P.; MARTINEZ-CAMPOS, M.; SOHRMANN, M; AHRINGER, J. Functional genomic analysis of $C$. elegans chromosome I by systematic RNA interference. Nature, v. 408, p. 325-330, 2000.

FUGÈRE, M.; DAY, R. Cutting back on proprotein convertases: the latest approaches to pharmacological inhibition. Trends in Pharmacological Sciences, v. 26, n. 6, p. 294-301, 2005.

FUKUSHIGE, T.; HENDZEL, M.J.; BAZETT-JONES, D.P.; MCGHEE, J.D. Direct visualization of the elt-2 gut-specific GATA factor binding to a target promoter inside the living Caenorhabditis elegans embryo. Proceedings of the National Academy of Sciences of the United States of America, v. 96, n. 21, p. 1188311888, 1999.

FULLER R.S., STERNE R.E.; THORNER J. Enzymes required for yeast prohormone processing. Annual Reviews of Physiology, v. 50, p. 345-362, 1988.

GELDHOF, P.; VISSER, A.; CLARK, D.; SAUNDERS, G.; BRITTON, C.; GILLEARD, J.; BERRIMAN, M.; KNOX, D. RNA interference in parasitic helminthes: current situation, potential pitfalls and future prospects. Parasitology, v. 134, p. 609-619, 2007.

GEREBR-HUBER, S.; NARDELLI, D.; HAEFLIGER, J-A.; COOPER, D.N.; GIVEL, F.; GERMOND, J-E.; ENGEL, J.; GREEN, M.; WAHLI, W. Precursor-product relationship between vitellogenin and the yolk proteins as derived from the complete sequence of a Xaenopus vitellogenin gene. Nucleic Acids Research, v. 15, p. 4737-4760, 1987.

GÓMEZ-SALADÍN E., LUEBKE A.E., WILSON D.L.; DICKERSON I.M. Isolation of a cDNA encoding a Kex2-like endoprotease with homology to furin from the nematode Caenorhabditis elegans. DNA and Cell Biology, v. 16, p. 663-669, 1997.

GÓMEZ-SALADÍN, E.; WILSON, D.L.; DICKERSON, I.M. Isolation and in situ localization of a cDNA encoding a Kex2-like prohormone convertase in the nematode Caenorhabditis elegans. Cellular and Molecular Neurobiology, v. 14, n. 1, p. 9-25, 1994.

GRANATO, M.; SCHNABEL, H.; SCHNABEL, R. pha-1, a selectable marker for gene transfer in C. elegans. Nucleic Acids Research, v. 22, n. 9, p. 1762-1763, 1994.

GRANT, B.D.; HIRSH, D. Receptor-mediated endocytosis in the Caenorhabditis elegans oocyte. Molecular Biology of the Cell, v. 10, p. 4311-4326, 1999.

GRISHOK, A. RNAi mechanisms in Caenorhabditis elegans. FEBS Letters, v. 579, p. 5932-5939, 2005.

GUPTA, M.C.; GRAHAM, P.L.; KRAMER, J.M. Characterization of alpha1(IV) collagen mutations in Caenorhabditis elegans and the effects of alpha1 and alpha2(IV) mutations on type IV collagen distribution. Journal of Cell Biology, v. 137, n. 5, p. 1185-1196, 1997.

HANNON, G.J. RNA interference. Nature, v. 418, p. 244-251, 2002. 
HART, A.C.; KASS, J.; SHAPIRO, J.E.; KAPLAN, J.M. Distinct signaling pathways mediate touch and osmosensory responses in a polymodal sensory neuron. The Journal of Neuroscience, v. 19, n. 6, 1952-1958, 1999.

HE, M.; WILDE, A.; KADERBHAI, M.A. A simple single-step procedure for small-scale preparation of Escherichia coli plasmids. Nucleic Acids Research, v. 18, n. 6, p. 1660, 1990.

HENRICH, S.; CAMERON, A.; BOURENKOV, G.P.; KIEFERSAUER, R.; HUBER, R.; LINDBERG, I.; BODE, W.; THAN, M.E. The crystal structure of the proprotein processing proteinase furin explains its stringent specificity. Nature Structural Biology, v. 10, n. 7, p. 520-527, 2003.

HERMANN, G.J.; SCHROEDER, L.K.; HIEB, C.A.; KERSHNER, A.M.; RABBITTS, B.M.; FONAREV, P.; GRANT, B.D.; PRIESS, J.R. Genetic analysis of lysosomal trafficking in Caenorhabditis elegans. Molecular Biology of the Cell, v. 16, p. 3273-3288, 2005.

HIRAMATSU, N.; ICHIKAWA, N.; FUKUDA, H.; FUJITA, T.; SULLIVAN, C.V.; HARA, A. Identification and characterization of proteases involved in specific proteolysis of vitellogenin and yolk proteins in salmonids. Journal of Experimental Zoology, v., 292, n. 1, p. 11-25, 2002.

HOLYOAK, T.; KETTNER, C.A.; PETSKO, G.A.; FULLER, R.S.; RINGE, D. Structural basis for differences in substrate selectivity in Kex2 and Furin Protein Convertases. Biochemistry, v. 43, p. 2412-2421, 2004.

HUNT-NEWBURY, R.; VIVEIROS, R.; JOHNSEN, R.; MAH, A.; ANASTAS, D.; FANG, L.; HALFNIGHT, E.; LEE, D.; LIN, J.; LORCH, A.; McKAY, S.; OKADA, H.M.; PAN, J.; SCHULZ, A.K.; TU, D.; WONG, K.; ZHAO, Z.; ALEXEYENKO, A.; BURGLIN, T.; SONNHAMMER, E.; SCHNABEL, R.; JACOB, T.C.; KAPLAN, J.M. High-trhoughput in vivo analysis of gene expression in Caenorhabditis elegans. PLoS Biology, v. 5, n. 9, p. e237, 2007.

HUSSEIN, A.S.; KICHENIN, K.; SELKIRK, M.E. Supression of secreted acetylcholinesterase expression in Nippostrongylus brasiliensis by RNA interference. Molecular and Biochemical Parasitology, v. 122, p. 91-94, 2002.

HUSSON, S.J.; CLYNEN, E.; BAGGERMAN, G.; JANSSEN, T.; SCHOOFS, L. Defective processing of neuropeptide precursors in Caenorhabditis elegans lacking proprotein convertase 2 (KPC-2/EGL-3): mutant analysis by mass spectrometry. Journal of Neurochemistry, v. 98, p. 1999-2012, 2006.

ISLAM, M.K.; MIYOSHI, T.; YAMADA, M.; TSUJI, N. Pyrophosphatase of the roundworm Ascaris suum plays an essential role in the worm's molting and development. Infection and Immunity, v. 73, p. 1995-2004, 2005.

JACOB, T.C.; KAPLAN, J.M. The EGL-21 carboxypeptidase E facilitates acetylcholine release at Caenorhabditis elegans neuromuscular junctions. The Journal of Neuroscience, v. 23, n. 6, p. 2122-2130, 2003.

JARRIAULT, S.; GREENWALD, I. Evidence for functional redundancy between C. elegans ADAM proteins SUP-17/Kuzbanian and ADM-4/TACE. Developmental Biology, v. 287, n. 1, p. 1-10, 2005.

JIN, J; POOLE, C.B.; SLATKO, B.E.; McREYNOLDS, L.A. Alternative splicing creates sex-specific transcripts and truncated forms of the furin protease in the parasite Dirofilaria immitis. Gene. v. 237, n. 1, p. 161-175, 1999.

JONES, S.J.; MARRA, M.A.; BAILLIE, D.L.; MOERMAN, D.G. High-throughput in vivo analysis os gene expression in Caenorhabditis elegans. PLOS Biology, v. 5, n. 9, p. 1981-1997, 2007.

JORGENSEN, E.M.; MANGO, S.E. The art and design of genetic screens: Caenorhabditis elegans. Nature Reviews Genetics, v. 3, p. 356-369, 2002.

JOSE, A.M.; HUNTER, C.P. Transport of sequence-specific RNA interference information between cells. Annual Reviews in Genetics, v. 41, p. 305-330, 2007.

KAMATH, R.S.; MARTINEZ-CAMPOS, M.; ZIPPERLEN, P.; FRASER, A.G.; AHRINGER, J. Effectiveness of specific RNA-mediated interference through ingested double-stranded RNA in Caenorhabditis elegans. Genome Biology, v. 2, n. 1, p. 0002.1-0002.10, 2001.

KASS, J.; JACOB, T. C.; KIM, P.; KAPLAN, J. M. The EGL-3 proprotein convertase regulates mechanosensory responses of Caenorhabditis elegans. Journal of Neurosciences, v. 21, p. 9265-9272, 2001.

KENNERDELL, J.R.; CARTHEW, R.W. Use of dsRNA-mediated genetic interference to demonstrate that frizzled and frizzled 2 act in the wingless pathway. Cell, v.95, p. 1017-1026, 1998. 
KIMBLE, J.; SHARROCK, W.J. Tissue-specific synthesis of yolk proteins in Caenorhabditis elegans. Developmental Biology, v. 96, p. 189-196, 1983.

KOSTROUCHOVA, M.; KRAUSE, M.; KOSTROUCH, Z.; RALL, J.E. Nuclear hormone receptor CHR3 is a critical regulator of all four larval moults of the nematode Caenorhabditis elegans. Proceedings of the National Academy of Sciences of the United States of America, v. 98, n. 13, p. 7360-7365, 2001.

KRAMER, J.M; JOHNSON, J.J. Analysis of mutations in the sqt-1 and rol-6 collagen genes of Caenorhabditis elegans. Genetics, v. 135, n. 4, p. 1035-1045, 1993.

KUERVERS, L.M.; JONES, C.L.; O'NEIL, N.J. BAILLIE, D.L. The sterol modifying enzyme LET-767 is essential for growth, reproduction and development in Caenorhabditis elegans. Molecular Genetics and Genomics, v. 270, p. 121-131, 2003.

KUHN, S.L.; ZIPFEL, P.F. The baculovirus expression vector pBSV-8His directs secretion of histidine-tagged proteins. Gene, v. 162, p. 225-229, 1995.

LAEMNLI, U. K. Cleavage of structural proteins during the assembly of the head of bacteriophage T4. Nature, v. 227, p. 680-685, 1970.

MACMORRIS, M.; SPIETH, J.; MADEJ, C.; LEA, K.; BLUMENTHAL, T. Analysis of VPE sequences in the Caenorhabditis elegans. Molecular and Cellular Biology, v. 14, n. 1, p. 484-491, 1994.

MADURO, M.F.; ROTHMAN, J.H. Making worm guts: the gene regulatory network of the Caenorhabditis elegans endoderm. Developmental Biology, v. 246, p. 68-85, 2002.

MAEDA, I.; KOHARA, Y.; YAMAMOTO, M.; SUGIMOTO, A. Large-scale analysis of gene function in Caenorhabditis elegans by high-throughput RNAi. Current Biology, v. 11, n. 3, p. 171-176, 2001.

MAHONEY, T.R.; LUO, S.; ROUND, E.K.; BRAUNER, M.; GOTTSCHALK, A.; THOMAS, J.H. Intestinal signaling to GABAergic neurons regulates a rhythmic behavior in Caenorhabditis elegans. Proceedings of the National Academy of Sciences of the United States of America, v. 105, n. 42, p. 16350-16355, 2008.

MAINE, E.M.; HAUTH, J.; RATLIFF, T.; VOUGHT, V.E.; SHE, X. EGO-1, a putative RNA-dependent RNA polymerase, is required for heterochromatin assembly on unpaired DNA during C. elegans meiosis. Current Biology, v. 15, p. 1972-1978, 2005.

MAIZEL Jr, J.V.; LENK, R.P. Enhanced graphic matrix analysis of nucleic acid and protein sequence. Proceedings of the National Academy of Sciences, Genetics, USA, v. 78, n. 12, p. 7655-7669, 1981.

MCGHEE, J.D.; SLEUMER, M.C.; BILENKY, M.; WONG, K.; McKAY, S.J.; GOSZCYNSKI, B.; TIAN, H.; KRICH, N.D.; KHATTRA, J.; HOLT, R.A.; BAILLIE, D.L.; KOHARA, Y.; MARRA, M.A.; JONES, S.J.M.; MOERMAN, D.G.; ROBERTSON, A.G. The ELT-2 GATA-factor and the global regulation of transcription in the C. elegans intestine. Developmental Biology, v. 302, p. 627-645, 2007.

McINTIRE, S.L.; JORGENSEN, E.; KAPLAN, J.; HORVITZ, H.R. The GABAergic nervous system of Caenorhabditis elegans. Nature, v. 364, p. 337-341, 1993.

MELDAL, B.H.; DEBENHAM, N.J.; DE LEY, P.; DE LEY, I.T.; VANFLETEREN, J.R.; VIERSTRAETE, A.R.; BERT, W.; BORGONIE, G.; MOENS, T.; TYLER, P.A.; AUSTEN, M.C.; BLAXTER, M.L.; ROGERS, A.D.; LAMBSHEAD, P.J. An improved molecular phylogeny of the Nematoda with special emphasis on marine taxa. Molecular Phylogenetics and Evolution, v. 42, n.3, p. 622-636, 2007.

MELO, A. C. A.; VALLE, D.; MACHADO, E. A.; SALERNO, A. P.; PAIVA-SILVA, G. O.; SILVA, N. L. C. E.; DE SOUZA, W.; MASUDA H. Synthesis of vitellogenin by the follicle cells of Rhodnius prolixus. Insect Biochemistry and Molecular Biology, v. 30, p. 549-557, 2000.

MILLER, S.A.; THATHY, V.; AJIOKA, J.W.; BLACKMAN, M.J.; KIM, K. TgSUB2 is a Toxoplasma gondii rhoptry organelle pocessing proteinase. Molecular Microbiology, v. 49, n. 4, p. 883-894, 2003.

MOLLOY, S. S.; ANDERSON, E. D.; JEAN, F.; THOMAS, G. Bi-cycling the furin pathway: from TGN localization to pathogen activation and embryogenesis. Trends in Cell Biology, v. 9, p. 28-35, 1999.

NAKAYAMA, K. Furin: a mammalian subtilisin/kex2p-like endoprotease involved in processing of a wide variety of precursor proteins. Biochemical Journal, v. 327, p. 625-635, 1997.

NEURATH, H. Proteolytic enzymes, past and future. Proceedings of the National Academy of Sciences of the United States of America, v, 96, p. 10962-10963, 1999. 
NIGON, V.; DOUGHERTY, E.C. Reproductive patterns and attempts at reciprocal crossing of Rhabditis elegans Maupas, 1900, and Rhabditis briggsae Dougherty \& Nigon. Journal of Experimental Zoology, v. 112, p. 485-503, 1949.

O'REILLY, D. R.; MILLER, L. K.; LUCKOW, V. A. Baculovirus Expression vectors: a laboratory manual. Oxford: Oxford University Press, 1994. 364 p.

OKKEMA, P.G.; KRAUSE, M. Transcriptional regulation. In: WormBook. ed. The C. elegans Research Community, 2005. p. 1-40.

PAGE, A.D.; JOHNSTONE, I.L. The cuticle. In: WormBook. ed. The C. elegans Research Community, 2007. p. 1-15.

PAGE, A.P.; WINTER, A.D. Enzymes involved in the biogenesis of the nematode cuticle. Advances in Parasitology, v. 53, p. 85-148, 2003.

PAK, J.; FIRE, A. Distinct populations of primary and secondary effectors during RNAi in C. elegans. Science, v. 315, p. 241-244, 2007.

PARKINSON, J.; MITREVA, M.; WHITTON, C.; THOMSON, M.; DAUB, J.; MARTIN, J.; SCHMID, R,; HALL, N.; BARRELL, B.; WATERSTON, R.H.; McCARTER, J.P.; BLAXTER, M.L. A transcriptomic analysis of the phylum Nematoda. Nature Genetics, v. 36, p. 1259-1267, 2004.

PAULI, F.; LIU, Y.; KIM, Y.A.; CHEN, P.-J.; KIM, S.K. Chromosomal clustering and GATA transcriptional regulation of intestine-expressed genes in C. elegans. Development, v. 133, p. 287-295, 2006.

PENHA-SACARABOTTO, C. Análise molecular dos polipeptídeos codificados no gene CEW1-vit-6 do nematóides Oscheius n.sp. Tese de doutorado apresentada ao Instituto de Ciências Biomédicas da Universidade de São Paulo, 1999.

PETERS, K. R.; McDOWALL, J. S.; ROSE, A. M. Mutations in the bli-4 locus of Caenorhabditis elegans disrupt both adult cuticle and early larval development. Genetics, v. 129, p. 95-102, 1991.

POOLE, C.B.; JINGMIN, J.; McREYNOLDS, L.A. Cloning and biochemical characterization of blisterase, a subtilisin-like convertase from the filarial parasite Onchocerca volvulus. Journal of Biological Chemistry, v. 278, n. 38, p. 36183-36190, 2003.

POSTHAUS, H.; DUBOIS, C.M.; LAPRISE, MH; GRONDIN, F.; SUTER, M.M.; MULLEWR, E. Proprotein cleavage of E-cadherin by furin in baculovirus over-expression system: potential role of other convertases in mammalian cells. Federation of European Biochemical Societies Letters, v. 438, p. 306-310, 1998.

RAMOS, C. R. R.; ABREU, P. A. E.; NASCIMENTO, A. L. T. O.; HO, P. L. A high-copy T7 Escherichia coli expression vector for the production of recombinant proteins with a minimal N-terminal His-tagged fusion peptide. Brazilian Journal of Medical and Biological Research, v. 37, n. 8, p. 1103-1109, 2004.

REECE-HOYES, J.S.; SHINGLES, J.; DUPUY, D.; GROVE, C.A.; WALHOUT, A.J.; VIDAL, M.; HOPE, I.A. Insight into transcription factor gene duplication from Caenorhabditis elegans Promoterome-driven expression patterns. BMC Genomics, v. 23, p. 8-27, 2007.

REINER, D.J.; WEINSHENKER, D.; THOMAS, J.H. Analysis of dominant mutations affecting muscle excitation in Caenorhabditis elegans. Genetics, v. 141, n. 3, p. 961-976, 1995.

RIDDLE, D.L.; BLUMENTHAL, T.; MEYER, B.J.; PRIESS, J.R. C. elegans II. Nova Iorque, EUA: Cold Spring Harbor Laboratory Press, 1997. 1222 p.

ROEBROEK, A.J.; SCHALKEN, J.A.; BUSSEMAKERS, M.J.; VAN HEERIKHUIZEN, H.; ONNEKINK, C.; DEBRUYNE, F.M.; BLOEMERS, H.P.; VAN DE VEN, W.J. Characterization of human c-fes/fps reveals a new transcription unit (fur) in the immediately upstream region of the proto-oncogene. Molecular Biology of Reproduction, v. 11, p. 117-125, 1986.

ROEBROOK, A.J.; TAYLOR, N.A.; LOUAGIE,E.; PAULI, I.; SMEIJERS, L.; SNELLIX, A.; LAUWERS, A.; VAN de VEN, W.J.; HARTMANN, D.; CREEMERS, J.W. Limited redundancy of the proprotein convertase furin in mouse liver. Journal of Biological Chemistry, v. 279, p. 53442-53450, 2004. 
SAJID, M.; WITHERS-MARTINEZ, C.; BLACKMAN, M.J. Maturation and specificity of Plasmodium falciparum subtilisin-like protease-1, a malaria merozoite subtilisin-like serine protease. Journal of Biological Chemistry, v. 275, n. 1, p. 631-641, 2000.

SAMBROOK, J.; FRITSCH, E.F.; MANIATIS, T. Molecular cloning: a laboratory manual. Ed. 2. New York: Cold Spring Harbor Laboratory Press, 1989. 1659 p.

SAPPINGTON, T. W.; OISHI, K.; RAIKHEL, A. S. Structural characteristics of insect vitellogenins. In: Reproductive biology of invertebrates, 2002. Cap. 12-A, 103-130.

SAPPINGTON, T.W.; RAIKHEL, A.S. Molecular characteristics of insect vitellogenins and vitellogenin receptors. Insect Biochemistry and Molecular Biology, v. 28, p. 277-300, 1998.

SAPPINGTON, T.W.; KOKOZA, V.A.; CHO, W.L.; RAIKHEL, A.S. Molecular characterization of the mosquito vitellogenin receptor reveals unexpected high homology to the Drosophila yolk protein receptor. Proceedings of the National Academy of Sciences of the United States of America, v. 93, n. 17, p. 89348939, 1996.

SATO, M.; SATO, K.; FONAREV, P.; HUANG, C-J.; LIOU, W.; GRANT, B.D. Caenorhabditis elegans RME6 is a novel regulator of RAB-5 at the clathrin-coated pit. Nature Cell Biology, v. 7, n. 6, p. 559-569, 2005.

SCHAGGER, H.; VON JAGOW, G. Tricine-sodium Dodecyl Sulfate-Polyacrilamide gel electrophoresis for the separation of proteins in the range 1 to 100kDa. Analytical Biochemistry, v. 166, n. 2, p. 368-379, 1987.

SCHULER, G.D. Sequence mapping by electronic PCR. Genome Research, v. 7, n. 5, p. 541-550, 1997.

SCHUMAN, S. Novel approach to molecular cloning and polynucleotide synthesis using Vaccinia DNA topoisomerase. Journal of Biological Chemistry, v. 269, p. 32678-684, 1994.

SEIDAH, N.G.; CHRÉTIEN, M. Eukaryotic protein processing: endoproteolysis of precursor proteins. Current Opinion in Biotechnology, v. 8, p. 602-607, 1997.

SHARROCK, W.J. Cleavage of two yolk proteins from a precursor in Caenorhabditis elegans. Journal of Molecular Biology, v. 174, n. 3, p. 419-431, 1984.

SHARROCK, W.J.; SUTHERLIN, M.E.; LESKE, K.; CHENG, T.K.; KIM, T.Y. Two distinct lipoprotein complexes from Caenorhabditis elegans. Journal of Biological Chemistry, v. 265, n. 24, p. 14422-14431, 1990.

SHINDE, U.; INOUYE, M. Folding mediated by na intramolecular chaperone: autoprocessing pathway of the precursor resolved via a substrate assisted catalysis mechanism. Journal of Molecular Biology, v. 247, p. 390395, 1995.

SHINDE, U.; LI, Y.; CHATTERJEE, S.; INOUYE, M. Folding pathway mediated by an intramolecular chaperone. Proceedings of the National Academy os Sciences of the United States of America, v. 90, p. 6924-6928, 1993.

SIEGFRIED, G.; BASAK, A.; CROMLISH, J.A.; BENJANNET, S.; MARCINKIEWICZ, J.; CHRÉTIN, M.; SEIDAH, N.G.; KHATIB, A.M. The secretory proprotein convertases furin, PC5 and PC7 activate VEGF-C to induce tumorigenesis. The Journal of Clinical Investigation, v. 111, n. 11, p. 1723-1732, 2003.

SIEZEN, R.J.; CREEMERS, J.W.; VAN DE VEN, W.J. Homology modelling of the catalytic domain of human furin. A model for the eukaryotic subtilisin-like proprotein convertases. European Journal of Biochemistry, v. 222, n. 2, p. 255-266, 1994.

SIJEN, T.; FLEENOR, J.; SIMMER, F..; THISSEN, K.L.; PARRISH, S. On the role of RNA amplification in dsRNA-triggered gene silencing. Cell, v. 107, p. 465-476, 2001.

SIMMER, F.; TIJSTERMAN, M.; PARRISH, S.; KOUSHIKA, S.P.; NONET, M.L.; FIRE, A. AHRINGER, J.; PLASTERK, R.H.A. Loss of the putative RNA-directed RNA polymerase RRF-3 makes C. elegans hypersensitive to RNAi. Current Biology, v. 12, p. 1317-1319, 2002.

SMARDON, A.; SPOERKE, J.M.; STACEY, S.C.; KLEIN, M.E.; MAINE, E.M. EGO-1 is related to RNAdirected RNA polymerase and functions in germ-line development and RNA interference in C. elegans. Current Biology, v. 10, n. 4, p.169-178, 2000.

SMOLENAARS, M. M.; MADSEN, O.; RODENBURG, K. W.; VAN DER HORST, D.J. Molecular diversity and evolution of the large lipid transfer protein superfamily. Journal of Lipid Research, v. 48, n. 3, p. 489-502, 2007. 
SONNHAMMER, E.L.; DURBIN, R. A dot-matrix program with dynamic threshold control suited for genomic DNA and protein sequence analysis. Gene, v. 167, n. 1-2, p. GC1-GC10, 1995.

SPIETH, J.; BLUMENTHAL, T. The Caenorhabditis elegans vitellogenin gene family includes a gene encoding a distantly related protein. Molecular and Cellular Biology, v. 5, n. 10, p. 2495-2501, 1985.

SPIETH, J.; DENISON, K.; KIRTLAND, S.; CANE, J.; BLUMENTHAL, T. The C. elegans vitellogenin genes: short sequences repeats in the promoter regions and homology to the vertebrate genes. Nucleic Acids Research, v. 13, n. 14, p. 5283-5295, 1985.

SPIETH, J.; NETTLETON, M.; ZUCKER-APRISON, E.; LEA, K.; BLUMENTHAL, T. Vitellogenin motifs conserved in nematodes and vertebrates. Journal of Molecular Evolution, v. 32, n. 5, p. 429-438, 1991.

STEINER D.F. The protein convertases. Current Opinion in Chemical Biology, v. 2, p. 31-39, 1998.

STUDIER, F.W.; MOFFATT, B.A. Use of bacteriophage T7 RNA polymerase to direct selective high-level expression of cloned genes. Journal of Molecular Biology, v. 189, n. 1, p. 113-130, 1986.

SULSTON, J.; DEW, M.; BRENNER, S. Dopaminergic neurons in the nematode Caenorhabditis elegans. Journal of Comparative Neurology, v. 163, p. 215-226, 1975.

SULSTON, J.; HORVITZ, H.R.; KIMBLE. J. Cell lineage. In: WOOD, W.B.; COMMUNITY OF C. ELEGANS RESEARCHERS. The nematode Caenorhabditis elegans. New York: Cold Spring Harbor Laboratory Press, 1988. Appendix 3, p. 457-489.

SULSTON, J.E.; SCHIERENBERG, E.; WHITE, J.G.; THOMSON, J.N.. The embryonic cell lineage of the nematode Caenorhabditis elegans. Developmental Biology, v. 100, p. 64-119, 1983.

TABARA, H.; GRISHOK, A.; MELLO, C.C. RNAi in C. elegans: soaking in the genome sequence. Science, v. 282, n. 5388, p. 430-431, 1998.

TAKAHASHI, M.; HASUURA, Y.; NAKAMORI, S.; TAKAGI, H. Improved autoprocessing efficiency of mutant Subtilisins E with altered specificity by engineering of the pro-region. Journal of Biochemistry, v. 130, p. 99-106, 2001.

TAKAHASHI, S.; HATSUZAWA, K.; WATANABE, T.; MURAKAMI, K.; NAKAYAMA, K. Sequence requirements for endoproteolytic processing of precursor protein by furin: transfection and in vitro experiments. Journal of Biochemistry, v. 222, p. 47-52, 1994.

TAKIFF, H.E.; CHEN, S-M.; COURT, D.L. Genetic analysis of the rnc operon of E. coli. Journal of Bacteriology, v. 171, n. 5, p. 2581-2590, 1989.

TELFER, W.H. Insect yolk proteins: A progress report. In: Reproductive Biology of Invertebrates, 12-A, p. $30,67,2002$.

THACKER, C.; ROSE, A. M. A look at the C. elegans kex2/subtilisin-like proprotein convertase family. BioEssays, v. 22, p. 545-553, 2000.

THACKER, C.; PETERS, K. R.; SRAYKO, M. A.; ROSE, A. M. The bli-4 locus of Caenorhabditis elegans encodes structurally distinct kex2/subtilisin-like endoproteases essencial for early development and adult morphology. Genes and Development, v. 9, p. 956-971, 1995.

THACKER, C.; SHEPS, J.A.; ROSE, A.M. Caenorhabditis elegans dpy-5 is a cuticle procollagen processed by a proprotein convertase. Cellular and Molecular Life Sciences, v. 63, p. 1193-1204, 2006.

THACKER, C.; SRAYKO, M.; ROSE, A.M. Mutational analysis of bli-4/kpc-4 reveals critical residues required for proprotein convertase function in C. elegans. Gene, v. 252, p. 15-25, 2000.

THE C. elegans SEQUENCING CONSORTIUM. Genome sequence of the nematode C. elegans: a platform for investigating biology. Science, v. 282, p. 2012-2018, 1998.

THOMAS, G. Furin at the cutting edge: from protein traffic to embryogenesis and disease. Nature Reviews: Molecular Cell Biology, v. 3, p. 753-766, 2002.

THOMAS, J. H. Genetic analysis of defecation in Caenorhabditis elegans. Genetics, v. 124, p. 855-872, 1990.

TIMMONS, L.; COURT, D.L.; FIRE, A. Ingestion of bacterially expressed dsRNAs can produce specific and potent genetic interference in Caenorhabditis elegans. Gene, v. 263, p. 103-112, 2001.

TIMMONS, L.; FIRE, A. Specific interference by ingested dsRNA. Nature, v. 395, p.854-, 1998. 
TISCHLER, J.; LEHNER, B.; CHEN, N.; FRASER, A.G. Combinatorial RNA interference in Caenorhabditis elegans reveals that redundancy between gene duplicates can be maintained for more than 80 million years of evolution. Genome Biology, v. 7, R69, 2006.

TRENT, C.; TSUNG, N.; HORVITZ, R. Egg-laying defective mutants of the nematode Caenorhabditis elegans. Genetics, v. 104, p. 619-647, 1983.

ULLU, E.; TSHUDI, C.; CHAKRABORTY, T. RNA interference in protozoan parasites. Cell Microbiology, v. 6, p. 509-519, 2004.

VAN HET SCHIP, F.D.; SAMALlO, J.; BROOS, J.; OPHUIS, J.; MOJET, M.; GRUBER, M.; AB, G. Nucleotide sequence of a chicken vitellogenin and derived amino acid sequence of the encoded yolk precursor protein. Journal of Molecular Biology, v. 196, p. 245-260, 1987.

VILLENEUVE, P.; FELICIANGELI, S.; CROISSANDEAU, G.; SEIDAH, N.G.; MBIKAY, M.; KITABGI, P.; BEAUDET, A. Altered processing of the neurotensin/neuromedin N precursor in PC2 knock-down mice: a biochemical and immunohistochemical study. Journal of Neurochemistry, v. 82, p. 783-792, 2002.

WAHLI, W.; DAWID, I.B.; RYFFEL, G.V.; WEBER, R. Vitellogenesis and the vitellogenin gene family. Science, v. 212, p. 298-304, 1981.

WANG, H.; YAN, T.; TAN, J.T.; GONG, Z. A zebrafish vitellogenin gene (vg3) encodes novel vitellogenin without a phosvitin domain and may represent a primitive vertebrate vitellogenin gene. Gene, v. 256, n. 1-2, p. 303-310, 2000.

WARD, A.; LIU, J.; FENG, Z.; XU, X.Z.S. Light-sensitive neurons and channels mediate phototaxis in $C$. elegans. Nature Neuroscience, v. 11, n. 8, p. 916-922, 2008.

WARD, S.; THOMSON, N.; WHITE, J.G.; BRENNER, S. Electron microscopical reconstruction of the anterior sensory anatomy of the nematode Caenorhabditis elegans. Journal of Comparative Neurology, v. 160, n. 1, p. 313-337, 1975.

WATERSTON, R.H.; THOMSON, J.N.; BRENNER, S. Mutants with altered muscle structure of Caenorhabditis elegans. Developmental Biology, v. 77, n. 2, p. 271-302, 1980.

WENICK, A. S.; HOBERT, O. Genomic cis-Regulatory Architecture and trans-Acting Regulators of a Single Interneuron-Specific Gene Battery in C. elegans. Developmental Cell, v. 6, p. 757-770, 2004.

WHITE, J.G.; SOUTHGATE, E.; THOMSON, J.N.; BRENNER, S. The structure of the nervous system of Caenorhabditis elegans. Philosophical Transactions of the Royal Society B, v. 314, p. 1-340, 1986.

WIGHTMAN, B., HA, I.; RUVKUN, G. Posttranscriptional regulation of the heterochronic gene lin-14 by lin-4 mediates temporal pattern formation in C. elegans. Cell, v. 75, p. 855-862, 1993.

WILKINS, C.; DISHONGH, R.; MOORE, S.C.; WHITT, M.A.; CHOW, M.; MACHACA, K. RNA interference is an antiviral defense mechanism in Caenorhabditis elegans. Nature, v. 436, p. 1044-1047, 2005.

WILlIAMS, B. D.; SCHRANK, B.; HUYNH, C.; SHOWNKEEN, R.; WATERSTON, R. H. A genetic mapping system in Caenorhabditis elegans based on polymorphic sequence-tagged sites. Genetics, v. 131, n. 3, p. 609-624, 1992.

WINSTON, W. M.; MOLODOWITCH, C.; HUNTER, C. P. Systemic RNAi in C. elegans requires the putative transmembrane protein SID-1. Science, v. 295, p. 2456-2459, 2002.

WINTER, C.E.; PENHA, C.; BLUMENTHAL, T. Comparison of a vitellogenin gene between two distantly related Rhabditid nematode species. Molecular Biology and Evolution, v. 13, n. 5, p. 674-684, 1996.

WINTER, C.E. Yolk proteins and their precursors in non-arthropod protostomes, with emphasis on nematodes. In: RAIKHEL, A.S.; SAPPINGTON, T.W. (Ed.). Reproductive Biology of Invertebrates: Progress in vitellogenesis. Local: Enfield, Science Publishers, 2002. p. 1-28.

WOOD, W.B. Introduction to C. elegans biology. In: WOOD, W.B. The Nematode Caenorhabditis elegans. New York: Cold Spring Harbor, 1988. p. 243-335.

WORMATLAS: Introduction to $\boldsymbol{C}$. elegans anatomy. Banco de dados de comportamento e anatomia de $C$. elegans. [página na internet]. Nova Iorque: Albert Eisntein College of Medicine. Disponível em: $<\mathrm{http}$ ///www.wormatlas.org/handbook/anatomyintro/anatomyintro.htm>. Acesso em: 2008 mar. 15. 
WORMBASE. Banco de dados sobre Biologia e Genômica de C. elegans [página na internet]. EUA: California Institute of Technology, Cold Spring Harbor Laboratory, Washington University em St. Louis e The Wellcome Trust Sanger Institute. Disponível em: <http://www.wormbase.org>. Acesso em: 2008 set. 13.

YABUTA, Y.; TAKAGI, H.; INOUYE, M.; SHINDE, U. Folding pathway mediated by an intramolecular chaperone: propeptide release modulates activation precison of prosubtilisin. Journal of Biological Chemistry, v. 276, p. 44427-44434, 2001.

YANG, J.; KRAMER, J.M. In vitro mutagenesis of Caenorhabditis elegans cuticle collagens identifies potential subtilisin-like protease cleavage site and demonstrates that carboxyl domain disulfide bonding is required for normal function but not assembly. Molecular and Cellular Biology, v. 14, n. 4, p. 2722-2730, 1994.

YOCHEM, J.; HERMAN, R.K. Investigating C. elegans development through mosaic analysis. Development, v. 130, p. 4761-4768, 2003.

YOCHEM, J. Genetic mosaics. In: THE C. ELEGANS RESEARCH COMMUNITY. WormBook. Local: Editora, 2005. p. 1-6.

YOCHEM, J. Nomarski images for learning the anatomy, with tips for mosaic analysis. In: THE C. ELEGANS RESEARCH COMMUNITY. WormBook. Local: Editora, 2006. p. 1-47.

YOCHEM, J.; TUCK, S.; GREENWALD, I.; HAN, M. A gp330/megalin-related protein is required in the major epidermis of Caenorhabditis elegans for completion of molting. Development, v. 126, p. 597-606, 1999.

ZHOU, A.; MARTIN, S.; LIPKIND, G.; LAMENDOLA, J.; STEINER, D.F. Regulatory roles of the P domain of the subtilisin-like prohormone convertase. Journal of Biological Chemistry, v. 273, n. 18, p. 11107-11114, 1998.

ZHU, J.; HILL, R.J.; HEID, P.J.; FUKUYAMA, M.; SUGIMOTO, A.; PRIESS, J.R.; ROTHMAN, J.H. end-1 encodes an apparent GATA factor that specifies the endoderm precursor in Caenorhabditis elegans embryos. Genes and Development, v. 11, n. 21, p. 2883-2896, 1997. 